\title{
Effect of hypoxia and anoxia on invertebrate behaviour: ecological perspectives from species to community level
}

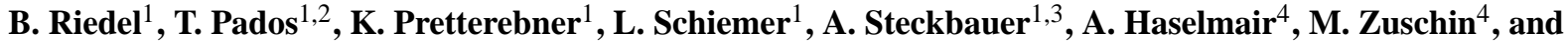 \\ M. Stachowitsch ${ }^{1}$ \\ ${ }^{1}$ University of Vienna, Department of Limnology and Bio-Oceanography, Vienna, Austria \\ ${ }^{2}$ University of Kiel, Helmholtz Zentrum für Ozeanforschung, GEOMAR, Kiel, Germany \\ ${ }^{3}$ IMEDEA (CSIC-UIB), Mediterranean Institute for Advanced Studies, Department of Global Change Research, Esporles, \\ Spain \\ ${ }^{4}$ University of Vienna, Department of Paleontology, Vienna, Austria
}

Correspondence to: B. Riedel (bettina.riedel@univie.ac.at)

Received: 28 June 2013 - Published in Biogeosciences Discuss.: 27 August 2013

Revised: 26 January 2014 - Accepted: 5 February 2014 - Published: 21 March 2014

\begin{abstract}
Coastal hypoxia and anoxia have become a global key stressor to marine ecosystems, with almost 500 dead zones recorded worldwide. By triggering cascading effects from the individual organism to the community- and ecosystem level, oxygen depletions threaten marine biodiversity and can alter ecosystem structure and function. By integrating both physiological function and ecological processes, animal behaviour is ideal for assessing the stress state of benthic macrofauna to low dissolved oxygen. The initial response of organisms can serve as an early warning signal, while the successive behavioural reactions of key species indicate hypoxia levels and help assess community degradation. Here we document the behavioural responses of a representative spectrum of benthic macrofauna in the natural setting in the Northern Adriatic Sea (Mediterranean). We experimentally induced small-scale anoxia with a benthic chamber in $24 \mathrm{~m}$ depth to overcome the difficulties in predicting the onset of hypoxia, which often hinders full documentation in the field. The behavioural reactions were documented with a time-lapse camera. Oxygen depletion elicited significant and repeatable changes in general (visibility, locomotion, body movement and posture, location) and species-specific reactions in virtually all organisms (302 individuals from 32 species and 2 species groups). Most atypical (stress) behaviours were associated with specific oxygen thresholds: arm-tipping in the ophiuroid Ophiothrix quinquemaculata, for example, with the onset of mild hypoxia $\left(<2 \mathrm{~mL} \mathrm{O}_{2} \mathrm{~L}^{-1}\right)$, the emergence of polychaetes on the sed-
\end{abstract}

iment surface with moderate hypoxia $\left(<1 \mathrm{~mL} \mathrm{O}_{2} \mathrm{~L}^{-1}\right)$, the emergence of the infaunal sea urchin Schizaster canaliferus on the sediment with severe hypoxia $\left(<0.5 \mathrm{~mL} \mathrm{O}_{2} \mathrm{~L}^{-1}\right)$ and heavy body rotations in sea anemones with anoxia. Other species changed their activity patterns, for example the circadian rhythm in the hermit crab Paguristes eremita or the bioherm-associated crab Pisidia longimana. Intra- and interspecific reactions were weakened or changed: decapods ceased defensive and territorial behaviour, and predator-prey interactions and relationships shifted. This nuanced scale of resolution is a useful tool to interpret present benthic community status (behaviour) and past mortalities (community composition, e.g. survival of tolerant species). This information on the sensitivity (onset of stress response), tolerance (mortality, survival), and characteristics (i.e. life habit, functional role) of key species also helps predict potential future changes in benthic structure and ecosystem functioning. This integrated approach can transport complex ecological processes to the public and decision-makers and help define specific monitoring, assessment and conservation plans.

\section{Introduction}

The increasing intensity and diversity of anthropogenic stressors is triggering unprecedented habitat and biodiversity loss in marine ecosystems worldwide (Halpern et al., 2008). The effects, ranging from population depletion to species 
extinction and community homogenisation, raise concerns whether ecosystem function and ecosystem goods and services can be maintained (UNEP, 2006; Worm et al., 2006; Cardinale et al., 2012). A key issue is understanding how species respond to such rapid human-induced environmental change (Sih et al., 2011; Tuomainen and Candolin, 2011).

Eutrophication is one of the most striking ecological threats to shallow coastal seas and estuaries (Smith and Schindler, 2009). Excessive nutrient inputs have the potential to tip systems into hypoxia (here defined as dissolved oxygen (DO) concentrations $<2 \mathrm{mLL}^{-1}$; about $2.8 \mathrm{mg} \mathrm{L}^{-1}$ or $91.4 \mu \mathrm{M}$; Diaz and Rosenberg, 1995) and anoxia (the complete absence of oxygen) or exacerbate conditions in predisposed areas (Gooday et al., 2009; Howarth et al., 2011).

Currently, the number of coastal eutrophic and hypoxic sites nearly touches the 500 mark (Diaz et al., 2011), with devastating effects for marine biodiversity and ecosystem functioning (Zhang et al., 2010). Ocean warming is expected to additionally increase the frequency, duration, intensity and extent of hypoxia/anoxia in certain zones (Keeling et al., 2010; Gruber, 2011), pushing coastal ecosystems toward tipping points (Conley et al., 2009; Rabalais et al., 2010) (Fig. 1).

Physiological and metabolic adaptations to hypoxia are the initial organismic responses (Grieshaber et al., 1994; Hagerman, 1998), and mortality the endpoint (Vaquer-Sunyer and Duarte, 2008; Riedel et al., 2012). Exposure to oxygen concentrations far above the lethal threshold already adversely affects growth, reproduction, locomotion and feeding (e.g. summarised in Gray et al., 2002; Wu, 2002; Levin et al., 2009). Importantly, basic behavioural activities are the link between individual responses and population changes (Boyd et al., 2002). Intraspecifically, for example, hypoxia affects mate choice or courtship behaviours in fish, impacting reproduction and development ( $\mathrm{Wu}, 2009)$. Change in one behaviour may influence the outcome of others, for example altered locomotion can affect reproduction and/or food finding behaviour (Boyd et al, 2002). Interspecifically, shifts in locomotion - migration to a new region, shallower burial depths or exposure atop elevated substrates - may change predator-prey relationships (Pihl et al., 1992; Riedel et al., 2008a; Long and Seitz, 2008). Behavioural parameters thus integrate direct and indirect responses across several levels of biological organisation, from individual fitness to community composition, reflecting cascading changes in biodiversity, biogeochemical processes and ecosystem function (e.g. Solan et al., 2004; Middelburg and Levin, 2009; Ekau et al., 2010; Zhang et al., 2010).

Such intimately nested responses call for more holistic approaches. Unexpected onsets of hypoxia, poorly predictable extents and the often rapid course of events are a challenge in gaining a better insight into when ecosystems approach critical points. This calls for recognising perturbations at the earliest possible stage, when adaptive capacity and resilience are still functional. The initial short-term reactions and atyp- ical behaviours of benthic macrofauna are a suitable avenue (summarised in Diaz and Rosenberg, 1995; Rabalais et al., 2001; Levin et al., 2009). For example, avoidance and altered migration patterns generally start when oxygen falls below $3.0 \mathrm{mg} \mathrm{L}^{-1}$ (equivalent to $2.1 \mathrm{mLL}^{-1}$ ). Such initial behavioural responses of benthic macrofauna integrate processes in the environment (from the sediment to the water body), yielding information beyond prevailing oxygen concentrations and species tolerance ranges to encompass overall ecosystem stress (e.g. Xu et al., 2006). This makes behaviour a suitable early warning indicator that also increases our understanding of longer-term ecosystem consequences (Tuomainen and Candolin, 2011). In the past, fishermen have for example provided crucial observations on "unusual" behaviour of fish and other animals that could ultimately be traced back to an ongoing or recent hypoxic/anoxic event, such as fishermen catching organisms that they normally do not catch or catching organisms at times and places where they are normally not caught. In the future, remote observation or scuba diving could be useful tools for initial or local hypoxia assessment, while the installation of underwater video networks on the seafloor might be an option to monitor larger areas and/or on a longer timescale.

Our in situ approach complements laboratory experiments, which provide detailed information on the individual organism level (e.g. respiration, growth rate and reproduction) but typically concentrate on captured animals of single species in artificial settings (Biro, 2012). The benthic chamber not only rivals the level of resolution in laboratory studies but also documents the complex biological interactions that accompany and define ecosystem responses to stress (Adams, 2003). Such multi-species analyses provide a very realistic and more holistic understanding of the complex structural and functional processes as well as potential species interactions in a community setting - a prerequisite for understanding ecosystem integrity (Culp et al., 2000; Sibley et al., 2000).

We hypothesised that certain (atypical) behaviours of benthic invertebrates are associated with distinct oxygen thresholds and that the behaviour of key species reliably indicates the status of benthic communities during hypoxia. We continuously recorded the multiple direct and indirect responses, including altered behaviours, inter- and intraspecific interactions and mortality sequences, of a sublittoral macrobenthic assemblage to hypoxia/anoxia in a realistic scenario. The benthic chamber induced small-scale anoxia in a benthic soft-bottom community setting in $24 \mathrm{~m}$ depth in the Northern Adriatic Sea. A time-lapse camera and sensors (oxygen, hydrogen sulphide, temperature, $\mathrm{pH}$ ) enabled continuous documentation of environmental parameters and biological responses. The focus was on the benthic macrofauna as the first component to visibly react to coastal hypoxia and the compartment that fundamentally defines such ecosystems and their functioning. The sediment-geochemical processes (Koron et al., 2013; Metzger et al., 2013), the accompanying 
Biodiversity, ecosystem function/integrity and services

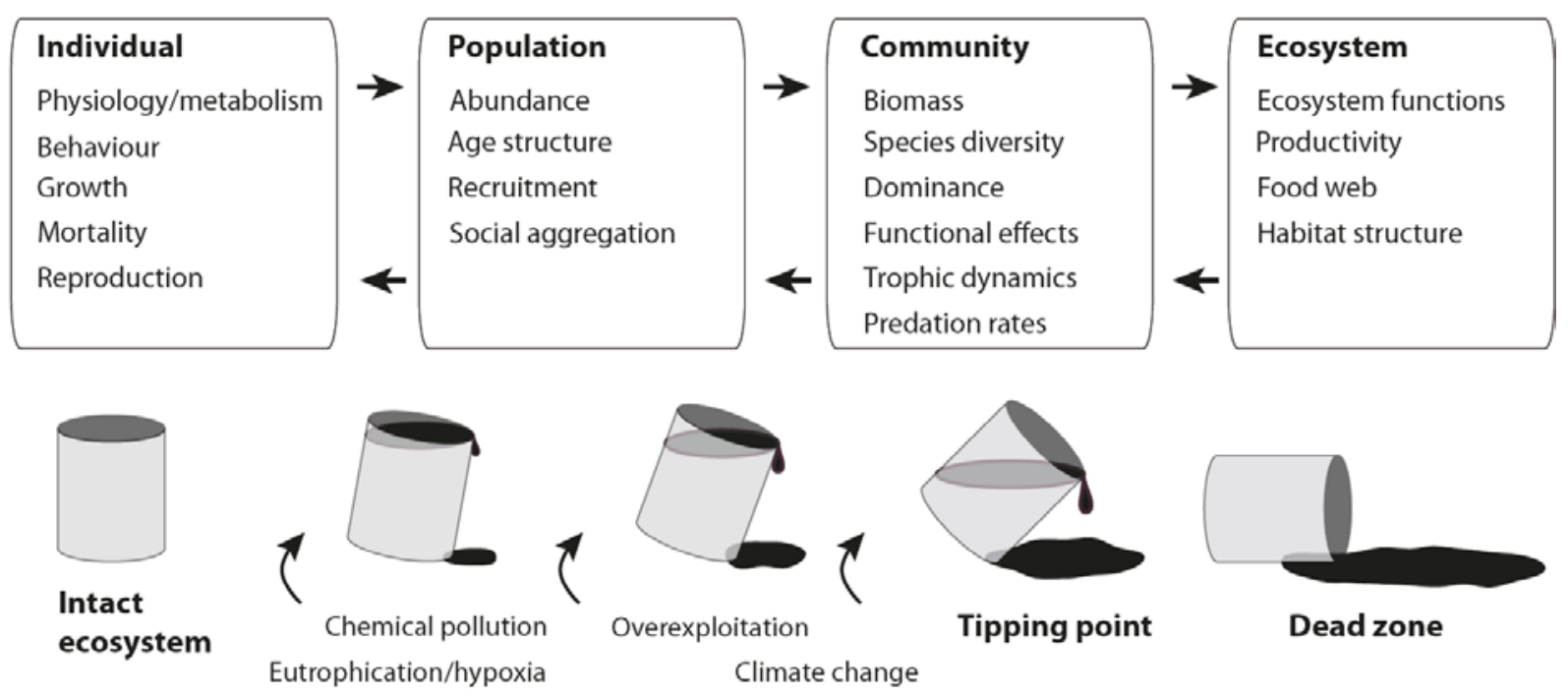

Fig. 1. Conceptual link between hypoxia and the multi-level effects in marine ecosystems. Hypoxia induces individual responses, which in turn affect population attributes, community dynamics and ultimately biodiversity and ecosystem integrity. The interactive and cumulative effects of multiple human stressors increasingly force the system to a critical tipping point and qualitatively altered state.

meiofauna responses (foraminiferans: Langlet et al. 2013a, b; harpacticoid copepods: Grego et al., 2013, 2014; De Troch et al., 2013), and immediate post-anoxia scavenging and longer-term recovery (Blasnig et al., 2013) are treated elsewhere in this special issue.

\section{Material and methods}

\subsection{Location and dates}

The Northern Adriatic Sea (Mediterranean) is a recognised area for seasonal low DO events (Malej and Malačič, 1995; Diaz and Rosenberg, 2008), here often associated with massive marine snow events (Danovaro et al., 2009 and references therein). The study site is located within and is representative of a wide-ranging, suspension-feeding macroepifauna community consisting of interspecific aggregations (multi-species clumps or bioherms) described as the Ophiothrix-Reniera-Microcosmus (ORM) community by Fedra et al. (1976).

Eleven deployments with a specially designed benthic chamber were made in 2005 (September) and 2006 (August to October) in a soft-bottom habitat (poorly sorted silty sand) in $24 \mathrm{~m}$ depth in the Gulf of Trieste $\left(45^{\circ} 32^{\prime} 55.68^{\prime \prime} \mathrm{N}\right.$, $\left.13^{\circ} 33^{\prime} 1.89^{\prime \prime} \mathrm{E}\right)$. This position, adjacent to the oceanographic buoy of the Marine Biology Station Piran, is not directly affected by bottom fisheries and had not experienced hypoxia for at least 5 years (V. Malačič, personal communication, 2005) before our experiment.

\subsection{Experimental procedure}

A benthic chamber was used to experimentally create smallscale anoxia and quantify macrobenthic responses to decreasing oxygen concentrations (for a detailed description of the method see Stachowitsch et al., 2007). The design involves the successive use of two interchangeable bases (both $50 \times 50 \times 50 \mathrm{~cm}$ ): an aluminum frame plus a separate instrument lid ("open" configuration) and a plexiglass chamber plus this same lid ("closed" configuration). Initially, the open configuration was positioned above a benthic assemblage for ca. $24 \mathrm{~h}$ to document macrobenthic behaviour during normoxia. Then, in a second step, the closed configuration was positioned for another 3 to 4 days above the same assemblage to document the reactions to hypoxia and anoxia. The plexiglass chamber was pressed ca. $4 \mathrm{~cm}$ into the sediment and prevented water exchange with the immediate environment. The instrument lid houses a time-lapse camera, 2 flashes, a data logger and the microsensor array for dissolved oxygen (DO), hydrogen sulphide $\left(\mathrm{H}_{2} \mathrm{~S}\right)$ and temperature recording (Unisense ${ }^{\circledR}$ ). Oxygen was measured 2 and $20 \mathrm{~cm}$ above the sediment to detect potential stratification and the $\mathrm{H}_{2} \mathrm{~S}$ sensor was positioned in $2 \mathrm{~cm}$ height. Bottom pH was measured at the beginning and the end of almost all deployments (WTW TA $197 \mathrm{pH}$ sensor). Images were taken in 6 min intervals, and microsensor values were logged every minute. 
Overall, about 10000 images were produced, yielding a documentation time of $1003 \mathrm{~h}$ (hypoxia: $331.9 \mathrm{~h}$, anoxia: $336.5 \mathrm{~h}$ ). The flashes never triggered any visible reaction in the benthic invertebrates and were thus not considered to have altered the course of the short-term experiments. Decreasing oxygen values in the chamber solely reflect natural respiration rates of the enclosed fauna (i.e. no macroalgae enclosed, photosynthesis by microflora under the low-light conditions in $24 \mathrm{~m}$ depth negligible). Although the chamber also cut off the food supply to suspension feeders, it is unlikely that this significantly affected the timing or sequence of mortalities in this group over the short experimental periods. The 11 deployments were similarly executed, but their durations varied somewhat due to weather/sea conditions. Four deployments started immediately with the closed configuration because of the highly turbid bottom water (for a summary of data and treatments in the 11 deployments see Appendix A, Table A1). After each deployment, living and dead organisms were collected and preserved in a $4 \%$ formalin-seawater solution. The experiments followed the institutional guidelines of the University of Vienna, Austria, and the Marine Biology Station Piran, Slovenia.

\subsection{Macrofauna data analysis}

The behaviour in a total of 302 individuals was evaluated, representing 32 species and 2 species groups (i.e. individuals unidentifiable based on the photographs). Time-lapse movies (Adobe Premiere Pro CS4) produced from the still image series provided quick viewing of the overall sequence of events (sample 4-day film available at http://phaidra.univie.ac.at/o: 87923). This yielded data on a representative spectrum of taxa, life habits, (stress) behaviours, interactions as well as on sensitivities (initial reactions) and tolerances (i.e. survival or mortality). Evaluated life habits include substrate relationships (cryptic and non-cryptic epifauna, infauna), mobility (mobile, sessile) and three major feeding types (predators, suspension feeders, deposit feeders) (Supplement Table S1). Species represented by only one or a few individuals were evaluated in full, those by many individuals selectively (those individuals most often visible and recognisable, for example the porcellanid crab Pisidia longimana). Each individual was analysed separately, image by image, and the behaviour recorded in categories (key categories of behaviours and responses listed below, for species-specific behaviours see Appendix A, Table A2; in 8 cases until they were predated: see Sect. 3.3.2 Predator-prey interactions). The terms "typical/normal" behaviour refer to responses observed during normoxia (in this study and earlier observations). Additional information on the hermit crab Paguristes eremita is provided in Pretterebner et al. (2012), and on decapods (except Alpheus glaber) in Haselmair et al. (2010). Mortality and/or survival in relation to hypoxia (DO concentration), anoxia (duration) and associated $\mathrm{H}_{2} \mathrm{~S}$ development was evaluated on an overall 495 individuals (39 species and 1 species group) based on the images and specimens collected after the deployment. The time-point of death was typically unambiguous, e.g. collapse of soft-bodied forms and various combinations of overturning, clear-cut body postures, discoloration. For more information on mortality/survival and life habits see Riedel et al. (2012).

\subsection{Key categories of behaviours and responses}

1. Visibility: visible, non-visible (hidden in/under bioherm, in sediment).

2. Locomotion: change in location (horizontal and/or vertical). Subcategories: minor (displacement $<1$ body length), major ( $>1$ body length), none.

3. Movement (other than locomotion): turn (change in direction), squirm, extremity movement (i.e. legs, antennae, eyes, chelipeds), body movement (i.e. body rotation in sea anemones, retraction into or stretching out of shell in hermit crabs, body contraction in ascidians).

4. Body posture: normal, atypical (posture never observed under normoxia).

5. Location: bottom (organism on sediment), middle ( $<5 \mathrm{~cm}$ above sediment, on macroepifauna), high/top ( $>5 \mathrm{~cm} /$ on top of bioherm).

6. Intra- and interspecific interaction: all encounters visibly triggering a change in behaviour, with focus on predator-prey relationships, atypical aggregation $(>3$ individuals in direct contact), aggression.

7. Species-specific responses (details: Appendix A, Table A2): e.g. pharynx protrusion and acontia discharge in sea anemone Calliactis parasitica, camouflage discarding (i.e. shell fragments) in echinoid Psammechinus microtuberculatus or decorator crab Ethusa mascarone.

\subsection{Statistical analysis and choice of oxygen units}

Assessing thresholds for hypoxia is critical and a widely debated issue. The units and terminology used to define hypoxia, as well as the conventional definition of when a critical oxygen concentration is reached, vary between and within earth and life sciences and their sub-disciplines (e.g. Rabalais et al., 2010). Even more fundamentally, there is no consensus on what limits the environmental oxygen supply (Verberk et al., 2011): ecologists, for example, typically emphasise oxygen solubility and express environmental oxygen in terms of concentration, while physiologists traditionally work with oxygen partial pressure (critical oxygen partial pressure $P_{\text {crit }}$ : the point at which oxyregulation by adjustments, i.e. increased blood pigment levels, enhanced ventilation or heart rate, breaks down; Seibel, 2011; Spicer, 2014). Nonetheless, and aware of the fact that static concentration 
thresholds do not consider temperature, pressure or flow rate dependency (Hofmann et al., 2013), our decision to work with $\mathrm{mL} \mathrm{L}^{-1}$ was motivated by comparability with the literature, that is, most research done on benthic fauna behaviour under low oxygen conditions - most notably the classical review by Diaz and Rosenberg (1995) - is based on this concentration unit.

Thus, behavioural data were assigned to five oxygen categories: normoxia $\left(\geq 2.0 \mathrm{mLDOL}^{-1}\right)$, mild $\left(<2.0 \mathrm{mLDOL}^{-1}\right)$, moderate $\left(<1.0 \mathrm{mLDOL}^{-1}\right)$, severe hypoxia $\left(<0.5 \mathrm{mLDOL}^{-1}\right)$, and anoxia (no oxygen). For selected behavioural reactions to hypoxia and anoxia in all species (groups) evaluated see Supplement Figs. S1-S33. Error bar graphs show the proportion of behaviours per oxygen category. The number of images evaluated per oxygen category (number below the $x$ axis) varies within and between species, depending on number of individuals evaluated per deployment, turbidity conditions (i.e. individual clearly identifiable), and deployment duration (including various oxygen category phases). In the pistol shrimp Alpheus glaber (both individuals in a deployment with an intermittent oxygen peak, see below in Results), the responses are depicted as histograms (Supplement Fig. S15), showing the number of behaviours observed per hour in relation to the oxygen curve (value averaged per hour). Significant $\mathrm{H}_{2} \mathrm{~S}$ refers to concentrations $>14 \mu \mathrm{M}$, as defined by Vaquer-Sunyer and Duarte (2010). The non-parametric Kruskal-Wallis test was used to determine potential differences in behaviours between oxygen categories, the Mann-Whitney $U$ test to test differences in the means of behaviours across oxygen categories. Categories with $<5$ images evaluated per oxygen category were excluded from statistical analysis. The significance level was $p<0.05$. Analyses were performed using SPSS software package 20.0.

\section{Results}

\subsection{Sensor data}

During the open-frame configuration, oxygen concentrations within a particular deployment remained relatively constant, although the values across all deployments ranged from 2.8 to $8.9 \mathrm{~mL} \mathrm{~L}^{-1} 20 \mathrm{~cm}$ above the sediment and 2.6 to $5.6 \mathrm{~mL} \mathrm{~L}^{-1}$ in $2 \mathrm{~cm}$ height, reflecting the respective meteorological/oceanographic conditions. The " $20 \mathrm{~cm}$ " values were typically higher. After closing the chamber, oxygen values fell constantly, with both curves approximating each other. The in situ approach successfully mimicked the actual time course of oxygen depletion events documented earlier in the Northern Adriatic based on macrofauna behaviour (Stachowitsch, 1984): hypoxia was generated within ca. 1.5 days, anoxia within 3 days (Appendix A, Table A1). At the transition from severe hypoxia to anoxia, the sediment colour

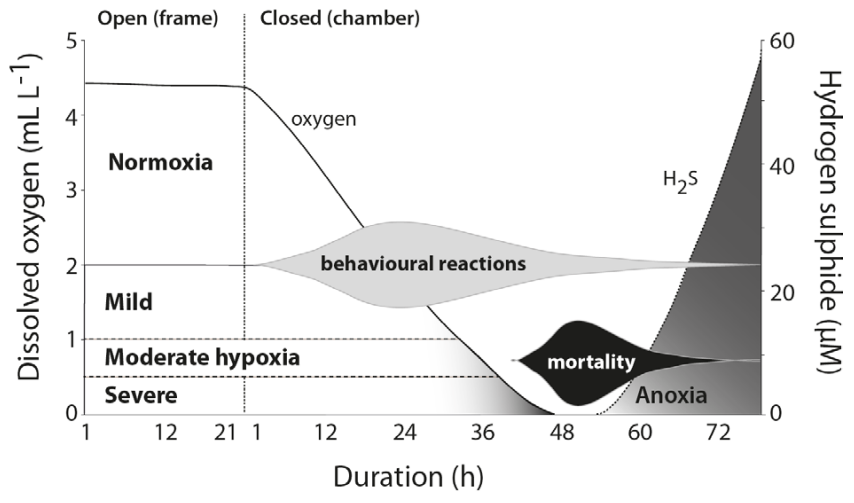

Fig. 2. Schematic course of all 11 deployments (oxygen, $\mathrm{H}_{2} \mathrm{~S}$, behaviour, mortality) based on averaged values in Table A1 (Appendix A). Hypoxia threshold at $2 \mathrm{~mL}$ dissolved oxygen [DO] $\mathrm{L}^{-1}$; dashed lines ( 1 and $0.5 \mathrm{~mL} \mathrm{DO} \mathrm{L}^{-1}$ ) separate different stages of hypoxia.

changed from brown-grey to darker grey and finally black with gradually increasing $\mathrm{H}_{2} \mathrm{~S}$ concentrations.

The rapidity of the oxygen decline varied between deployments, reflecting the biomass enclosed and initial oxygen concentrations. Accordingly, hypoxia duration ranged from 11.4 to $52.9 \mathrm{~h}$, anoxia 5.2 to $81.8 \mathrm{~h}$. In deployment 2 an intermittent oxygen peak created two phases of oxygen decline (Riedel et al., 2008b). $\mathrm{H}_{2} \mathrm{~S}$ development occurred in 10 of the 11 deployments after onset of anoxia, with final values (average over last hour of deployment) reaching $167.6 \mu \mathrm{M}$ (except deployment 11, with an intermittent peak of $300 \mu \mathrm{M}$ ). Temperature within a particular deployment remained constant (range across all experiments 17.6 to $21.4{ }^{\circ} \mathrm{C}$ ), bottom salinity was 38 . Bottom-water $\mathrm{pH}$ dropped from 8.2 to a mean of 7.8 (minimum 7.5). Figure 2 illustrates the course of a representative deployment based on average values from Table A1.

\subsection{Macrofauna behaviour}

Hypoxia elicited clear, visible reactions in all organisms. These reflected an increasing response to decreasing oxygen values and/or increasing duration of anoxia. Three main types of reactions were evident: altered activity levels and new (stress) behaviours; altered interactions; distinct sensitivities and tolerances.

1. Altered activity levels and atypical behaviours: the first reactions typically involved an increase and/or decrease in the level of normal activities and/or initiation of atypical stress behaviours. Almost all species showed a sequence of behaviours to decreasing oxygen concentrations. For species-/group-specific changes in behaviours across the five oxygen categories/thresholds see text and Tables 1 to 10 below and Figs. S1-S33 in Supplement; for a synthesis see Fig. 7. 


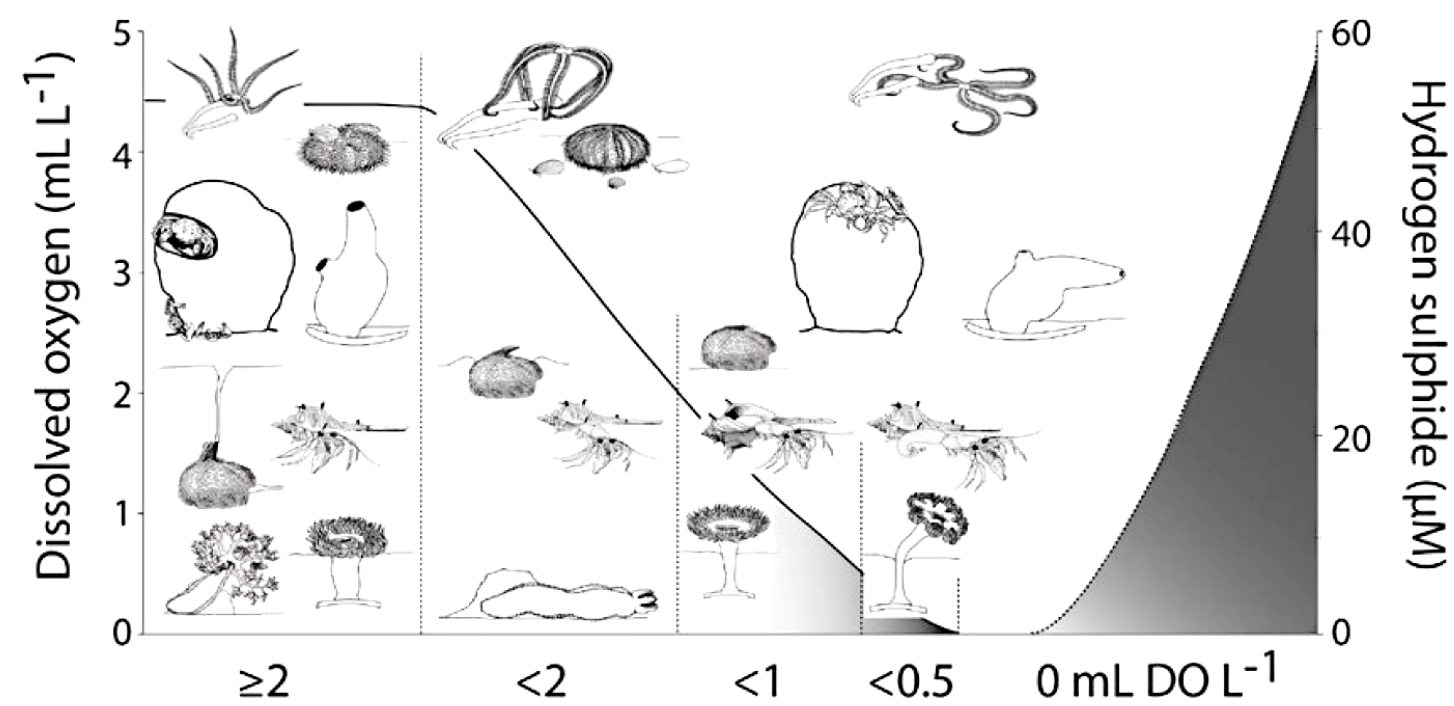

Fig. 3. Behavioural reactions of key species across oxygen concentrations/thresholds.

Importantly, within a species, almost all individuals' behaviours showed a nearly identical sequence. Most behaviours were clearly related to specific oxygen thresholds/categories (Fig. 3). This was supported by the results from deployment 2, where atypical behaviours were interrupted during the temporary reoxygenation and then resumed again at renewed hypoxia (e.g. Alpheus glaber Fig. S15 in Supplement; deployment details see Riedel et al., 2008b). Whereas epifauna typically showed first responses at early, mild hypoxia, the first visible response of the macroinfauna (emergence) started at moderate hypoxia (exceptions: bivalve Corbula gibba, brittle star Ophiura spp.).

2. Altered intra- and interspecific interactions: this included the weakening of defensive (i.e. hiding and covering behaviour) and territorial behaviour as well as altered predator-prey interactions, including unusual interactions and encounters (see Sect. 3.3).

3. Sensitivity and tolerance: our experiments revealed a distinct sequence of mortality, reflecting the sensitivity and tolerance of the species and higher taxa to decreasing oxygen concentrations and anoxia duration (see Sect. 3.4).

\subsection{Intra- and interspecific interactions}

Numerous interactions and resulting behavioural reactions were recorded during normoxic conditions. The tube worm Protula tubularia, for example, retracted its tentacle crown after a hermit crab touched the tube; brittle stars interrupted their filter-feeding posture and changed position on bioherms when touched by passing hermit crabs (and occasionally by the crabs' symbiotic sea anemone $C$. parasitica), while the anemone Cereus pedunculatus retracted into the sediment when approached by other organisms.

With decreasing oxygen concentrations, however, "normal" behavioural interactions weakened or ceased and atypical interactions and reactions, never observed under normoxia, were documented. Most obvious was the change in decapod defensive and territorial behaviour. Atypical predator-prey interactions involving sea anemones and brittle stars also occurred.

\subsubsection{Aggregation and aggressive behaviour}

Because of the hypoxia-related upward migration of the redox layer towards the sediment surface and the often very steep oxygen gradients near the sediment surface, moving only a few centimetres can mean the difference between tolerable and lethal conditions. Thus, most mobile in- and epifaunal organisms sought refuge from increasingly severe bottom hypoxia by moving onto elevated, better-oxygenated substrates above the sediment surface. Macroinfauna typically emerged onto the sediment surface (e.g. the sea urchin Schizaster canaliferus, the bivalve Corbula gibba), with many polychaetes further moving to elevated positions on the multi-species clumps. Many epifaunal species climbed on adjoining multi-species clumps (e.g. hermit crabs) or higher up on the substrate they inhabited (e.g. see Fig. 4b). Cryptic epifauna, i.e. the bioherm-associated crabs Pilumnus spinifer or Pisidia longimana emerged from hiding and aggregated on top of sponges and ascidians. Other mobile benthic invertebrates positioned themselves on atypical substrates, for example on mobile organisms avoided under normal oxygen conditions (e.g. the brittle star Ophiothrix quinquemaculata on hermit crabs, the hermit crab Paguristes eremita on sea urchins). The greatest number of aggregations as well as the 
Table 1. Table 1-10. Species-/group-specific changes in behaviour from normoxia to anoxia. Percent values: mean percent of observations of the respective behaviour during the five oxygen categories. Anthozoa. Calliactis parasitica: mutualistic symbiont associated with hermit crabs (up to three specimens/shell), sometimes also on living gastropods (Hexaplex trunculus). Column normally yellow/buff with darker vertical stripes. Non-selective omnivorous suspension feeder that also uses tentacles to sweep sediment; main prey: gastropods and crustaceans. Cereus pedunculatus: sea anemone buried in sediment, with tentacle crown flat on sediment surface; some specimens integrated into bioherms. Opportunistic omnivorous suspension feeder on organic detritus but also on mobile prey (amphipods and decapods).

\begin{tabular}{|c|c|c|}
\hline $\begin{array}{l}\text { DO } \\
\left(\mathrm{mLL}^{-1}\right)\end{array}$ & Behaviour per oxygen category & $\begin{array}{l}\text { Figs. } \\
\text { Suppl. }\end{array}$ \\
\hline \multicolumn{3}{|c|}{ Calliactis parasitica (Couch, 1842), $N=6$} \\
\hline$\geq 2.0$ & tentacle crown typically facing down, tentacles sweeping the sediment as the crab walks about. & \\
\hline$<2.0$ & $\begin{array}{l}\text { significant change in crown orientation from down- to upward }(51 \%) \text {. Marked increase in opened tentacle } \\
\text { crowns in all individuals }(90 \%) \text {. Sporadic slight body contractions (i.e. column diameter constricted or inflated). }\end{array}$ & S1d, b, f \\
\hline$<1.0$ & $\begin{array}{l}\text { peak upward orientation, tentacle crowns started to close again more often. Mouth occasionally "puckered"; } \\
\text { increased pharynx protrusion. }\end{array}$ & S1c, h \\
\hline$<0.5$ & $\begin{array}{l}\text { significant increase in body contractions and body rotations ( } 36 \text { and } 22 \% \text {, respectively); pharynx protrusion } \\
\text { reached } 43 \% \text {. Column turned greyish; at near-anoxia, periderm in one individual started to peel off and acontia } \\
\text { discharged. }\end{array}$ & S1g, a \\
\hline 0 & $\begin{array}{l}\text { initially (no } \mathrm{H}_{2} \mathrm{~S} \text { present), peak body contraction and rotation. With increasing } \mathrm{H}_{2} \mathrm{~S} \text { (ca. } 30 \mu \mathrm{M} \text { ), how- } \\
\text { ever, visible decrease in these activities: body relaxed, tentacle crowns (either half-open or closed) slightly } \\
\text { moved/pulsated, rotations almost ceased; only weak body contractions. Two individuals detached from shell } \\
\text { and fell to sediment, another individual discharged its acontia. Four individuals died after } 47.4 \text { to } 65.6 \mathrm{~h} \text { of } \\
\text { anoxia }\left(\mathrm{H}_{2} \mathrm{~S} \text { range: } 56.3-96.1 \mu \mathrm{M}\right) \text {, two survived } 25.1 \mathrm{~h} \text { of anoxia (final } \mathrm{H}_{2} \mathrm{~S} 124.5 \mu \mathrm{M} \text { ). }\end{array}$ & \\
\hline \multicolumn{3}{|c|}{ Cereus pedunculatus (Pennant, 1777), $N=17$} \\
\hline$\geq 2.0$ & specimens touched, e.g. by passing crabs, closed crown and briefly retracted into sediment. & \\
\hline$<2.0$ & $\begin{array}{l}\text { minor extensions (i.e. slightly above sediment surface); tentacle crowns increasingly stayed open when touched } \\
(57 \%) \text {; retraction into sediment dropped from } 33 \text { to } 20 \% \text {. }\end{array}$ & $\mathrm{S} 2 \mathrm{~h}, \mathrm{~b}, \mathrm{~d}$ \\
\hline$<1.0$ & $\begin{array}{l}\text { significant increase in minor extension ( } 21 \text { to } 60 \%) \text {. Crowns largely open, increased body contractions. Gradual } \\
\text { discolouration (paler) of tentacles and oral disc. }\end{array}$ & S2e, a \\
\hline$<0.5$ & $\begin{array}{l}\text { major extension (parts of column clearly visible) significantly increased }(51 \%) \text {; strong body contractions and } \\
\text { rotations pendulating in all directions); peak pharynx protrusion }(29 \%) .\end{array}$ & S2f, g \\
\hline 0 & $\begin{array}{l}\text { sharp increase in half-open and closed crowns (combined: } 61 \% \text { ). Body contractions and rotations continued } \\
\text { until end of deployments. All individuals survived (maximum anoxia duration } 81.8 \mathrm{~h} \text {; max. } \mathrm{H}_{2} \mathrm{~S} \text { concentration } \\
279 \mu \mathrm{M} \text { ). }\end{array}$ & $\mathrm{S} 2 \mathrm{c}$ \\
\hline
\end{tabular}

Table 2. Nemertini and Sipunculida. Tubulanus sp.: mobile, infaunal nemertean; predator on muddy sublittoral bottoms.

\begin{tabular}{lll}
\hline DO & Behaviour per oxygen category & Figs. \\
$\left(\mathrm{mLL}^{-1}\right)$ & & Suppl. \\
\hline
\end{tabular}

Tubulanus sp., $N=1$

$\geq 2.0-<0.5 \quad$ infaunal animal, not visible on sediment surface.

$0 \quad$ one large individual (ca. $40 \mathrm{~cm}$ ) emerged $18 \mathrm{~h}$ after onset of anoxia $\left(\mathrm{H}_{2} \mathrm{~S} 33.3 \mu \mathrm{M}\right)$ and then moved about on sediment or squirmed in place (75 and $21 \%$, respectively). On two occasions the nemertean was under and in direct contact with an emerged infauna sea urchin (Schizaster canaliferus; total interaction time ca. $1 \mathrm{~h}$ ), and also crawled under a holothurian (Ocnus planci; $>12 \mathrm{~min})$. At $26.4 \mathrm{~h}$ of anoxia $\left(\mathrm{H}_{2} \mathrm{~S} 41.7 \mu \mathrm{M}\right)$ it disappeared from view (i.e. mortality or survival not determined).

Sipunculida indet. species, $N=4$

$\geq 2.0-<1.0 \quad$ not visible on sediment surface.

$<0.5 \quad$ one individual emerged at transition from severe hypoxia to anoxia (hypoxia duration $33.5 \mathrm{~h}$ ) and showed minor movements and squirming in place.

$0 \quad$ three more individuals 7.6, 17.5 and $34.2 \mathrm{~h}$ after onset of anoxia $\left(\mathrm{H}_{2} \mathrm{~S} 34.9,83.2\right.$ and $\left.243.2 \mu \mathrm{M}\right)$. Most moved only short distances $(5 \%)$, tending to then squirm in place $(41 \%)$ rather than move about. Two individuals disappeared from view only 30 and 108 minutes after emergence (i.e. anoxia 9.5 and $34.8 \mathrm{~h}$ ) and may have reburied themselves; other two specimens visible on sediment surface until end of deployment (anoxia duration 24.2 and $25.1 \mathrm{~h}$, final $\mathrm{H}_{2} \mathrm{~S} 18.2$ and $124.5 \mu \mathrm{M}$, respectively). 
Table 3. Gastropoda. Diodora sp.: keyhole limpets are herbivores and browsing carnivores on hard substrata and inhabit bioherms. Fusinus rostratus: common predatory fasciolariid on Northern Adriatic sublittoral soft bottoms. Hexaplex trunculus: abundant and widespread muricid in the Northern Adriatic, exhibiting multiple predation strategies on bivalve prey. Experimental design played a role in behavioural response: individuals crawled up the plexiglass walls and sought the highest level (chamber lid). This nonetheless mirrors the natural response because muricids climb atop bioherms (Stachowitsch, 1984). Murex brandaris: spiny dye-murex, common on Northern Adriatic muddy bottoms.

\begin{tabular}{|c|c|c|}
\hline $\begin{array}{l}\mathrm{DO} \\
\left(\mathrm{mLL} \mathrm{L}^{-1}\right)\end{array}$ & Behaviour per oxygen category & $\begin{array}{l}\text { Figs. } \\
\text { Suppl. }\end{array}$ \\
\hline \multicolumn{3}{|c|}{ Diodora sp., $N=4$} \\
\hline$\geq 2.0$ & $\begin{array}{l}\text { only two of overall four specimens visible because of their cryptic position on multi-species clumps or cover by } \\
\text { brittle star aggregations. Individuals quite stationary. }\end{array}$ & S5a, b \\
\hline$<2.0$ & no significant change in behaviour. & \\
\hline$<1.0$ & $\begin{array}{l}\text { visibility significantly increased to } 72 \% \text {, with one individual emerging from under an ascidian at } 0.7 \mathrm{~mL} \mathrm{DO} \mathrm{L}^{-1} \text {. } \\
\text { Combination of foot extension and arm-tipping brittle stars Ophiothrix quinquemaculata (see below) simplified } \\
\text { recognition of limpets. One individual crawled onto a hermit crab (Paguristes eremita)-inhabited shell occupied by } \\
\text { three anemones (Calliactis parasitica). The limpet was in direct contact with the column of two of these anemones } \\
\text { for } 3.3 \mathrm{~h} \text {. At this point, crab extended from shell and motionless. Then, limpet movement caused crab's shell to } \\
\text { overturn over a period of } 48 \mathrm{~min} \text {. }\end{array}$ & S5a, d, \\
\hline$<0.5$ & $\begin{array}{l}\text { fourth specimen visible. All individuals started to flip over or fall off from their substrate, i.e. shell overturned in } \\
33 \% \text { of observations. Foot extension peaked ( } 37 \%) \text {. One individual climbed atop a sea urchin (Psammechinus mi- } \\
\text { crotuberculatus) for } 12 \mathrm{~min} \text { before falling off at border to anoxia. Second individual, on hermit crab shell, remained } \\
\text { firmly attached for } 26.2 \mathrm{~h} \text {, again in contact with both the anemones and the hermit crab, which repeatedly touched } \\
\text { the limpet with its pereopods and claws. First mortality shortly before onset of anoxia ( } 45.7 \mathrm{~h} \text { of hypoxia). }\end{array}$ & $\mathrm{S} 5 \mathrm{c}, \mathrm{d}$, \\
\hline 0 & $\begin{array}{l}\text { remaining three individuals flipped over }(76 \%) \text {. The limpet that fell off the sea urchin uprighted itself } 1 \mathrm{~h} \text { later, } \\
\text { before again falling over and remaining so until end of experiment } 4.2 \mathrm{~h} \text { later. Individual on hermit crab gradually } \\
\text { loosened its attachment and exposed most of its foot for } 5.6 \mathrm{~h} \text {, before falling off onto sediment, after which it no } \\
\text { longer moved despite being touched repeatedly by crab and its anemones. Two individuals died ( } 2.4 \text { and } 11 \mathrm{~h} \text { of } \\
\left.\text { anoxia; } \mathrm{H}_{2} \mathrm{~S} 46.6 \text { and } 5.6 \mu \mathrm{M}\right) \text {, one specimen survived (albeit in deployment with second shortest anoxia: } 8.5 \mathrm{~h} \text {, no } \\
\mathrm{H}_{2} \mathrm{~S} \text { ). }\end{array}$ & \\
\hline \multicolumn{3}{|c|}{ Fusinus rostratus (Olivi, 1792), $N=1$} \\
\hline $\begin{array}{l}\geq 2.0 \\
<2.0\end{array}$ & $\begin{array}{l}\text { the single detected individual well visible on sediment surface; horizontal locomotion negligible (3\%). } \\
\text { as under normoxia. }\end{array}$ & S6a, c \\
\hline$<1.0$ & as under normoxia, but peak horizontal locomotion $(29 \%)$ & \\
\hline$<0.5$ & $\begin{array}{l}\text { animal climbed higher on a multi-species clump; after short locomotion phase, remained stationary. Foot/head } \\
\text { alternately extended and retracted. Ultimately fell down and less often visible. }\end{array}$ & S6b \\
\hline 0 & $\begin{array}{l}\text { visibility drops further (to } 50 \% \text { ), with second peak in horizontal locomotion }(17 \%) \text {. In } 51 \% \text { of observations on } \\
\text { top of epifaunal aggregation; during stationary phases, foot/head visible. After } 40.6 \mathrm{~h} \text { of anoxia }\left(\mathrm{H}_{2} \mathrm{~S} 191.6 \mu \mathrm{M}\right) \text {, } \\
\text { animal disappeared from view (mortality or survival not determined). }\end{array}$ & \\
\hline \multicolumn{3}{|c|}{ Hexaplex trunculus (Linnaeus, 1758), $N=23$} \\
\hline$\geq 2.0$ & animals visible in $40 \%$ of observations, mostly on sediment/under bioherms, i.e. do not crawl up plexiglas wall. & S7a, b \\
\hline$<2.0$ & $\begin{array}{l}\text { first animals started to crawl up chamber wall: minimal increase in vertical movement }(7 \%) \text { reflects the few but } \\
\text { often major moves, leaving animals on chamber lid. }\end{array}$ & S7c \\
\hline$<1.0$ & increased tendency to be higher up in chamber. & \\
\hline$<0.5$ & $\begin{array}{l}\text { location on top of chamber peaked }(71 \%) \text {; the few individuals visible at the sediment surface started to protract } \\
\text { and/or retract their foot/head. }\end{array}$ & S7d \\
\hline 0 & $\begin{array}{l}\text { at end of deployments } 16 \text { animals not visible, probably on lid. } 7 \text { individuals fell to sediment from lid or bio- } \\
\text { herm, i.e. increase in visibility to pre-hypoxia values }(44 \%) \text {; peak in foot protractions/retractions ( } 11 \text { and } 24 \% \text {, } \\
\text { respectively). } H \text {. trunculus was among the species with the highest survival rates, i.e. only two mortalities at } 46.3 \\
\text { and } 51.5 \mathrm{~h} \text { of anoxia ( } 117.1 \text { and } 199.9 \mu \mathrm{M} \mathrm{H} \mathrm{H}_{2} \mathrm{~S} \text {, respectively). Survivors (max. anoxia duration } 81.8 \mathrm{~h} \text {; final } \mathrm{H}_{2} \mathrm{~S} \\
167.6 \mu \mathrm{M} \text { ) also included specimens which did not seek refuge at chamber top but remained on sediment surface or } \\
\text { bioherms throughout. }\end{array}$ & \\
\hline \multicolumn{3}{|c|}{ Murex brandaris (Linnaeus, 1758$), N=1$} \\
\hline $\begin{array}{l}2.0 \\
<20\end{array}$ & as in $H$. trunculus, visible in $43 \%$ of observations. As in all categories, stronger horizontal than vertical movements. & S8a, c \\
\hline$<1.0$ & peak horizontal movement $(69 \%)$ & \\
\hline$<0.5$ & $\begin{array}{l}\text { significant decrease in horizontal movement to } 9 \% \text {, but animal moved higher up on plexiglass wall (i.e. location } \\
\text { high/top: } 23 \% \text { ). }\end{array}$ & $\mathrm{S} 8 \mathrm{~b}$ \\
\hline 0 & $\begin{array}{l}\text { animal remained on plexiglass wall with no movement. Specimen survived (albeit in deployment with shortest } \\
\text { anoxia: } 5.2 \mathrm{~h} \text {, final } \mathrm{H}_{2} \mathrm{~S} 5.5 \mu \mathrm{M} \text { ). }\end{array}$ & \\
\hline
\end{tabular}


Table 4. Bivalvia. Abra alba: infaunal, deposit feeder common in the Northern Adriatic. Chlamys varia: suspension-feeding, epifaunal bivalve, typically bysally attached to bioherms. Corbula gibba: highly abundant, shallow infaunal suspension feeder. Venerupis cf. rhomboides: infaunal suspension feeder, widely distributed in the Northern Adriatic.

\begin{tabular}{|c|c|c|}
\hline $\begin{array}{l}\text { DO } \\
\left(\mathrm{mLL}^{-1}\right)\end{array}$ & Behaviour per oxygen category & $\begin{array}{l}\text { Figs. } \\
\text { Suppl. }\end{array}$ \\
\hline \multicolumn{3}{|c|}{ Abra alba (Wood, 1802), $N=2$} \\
\hline$\geq 2.0-<1.0$ & not visible. & \multirow{3}{*}{ S9a, b, c } \\
\hline$<0.5$ & animals emerged and made a series of short moves on the sediment. Siphons visible ( $35 \%)$ & \\
\hline 0 & $\begin{array}{l}\text { animals on surface, locomotion ceased, siphon visible only in one individual, which was pushed aside by } \\
\text { hermit crab (no predation/scavenging). Both individuals died (duration of anoxia } 20.6 \text { and } 34.6 \mathrm{~h}, \mathrm{H}_{2} \mathrm{~S} \\
33.3 \text { and } 244 \mu \mathrm{M} \text { ). }\end{array}$ & \\
\hline \multicolumn{3}{|c|}{ Chlamys varia (Linnaeus, 1758), $N=7$} \\
\hline$\geq 2.0$ & animals in feeding position with normal (open) shell gape and mantle tissue visible ( 97 and $99 \%$ ). & \multirow{3}{*}{$\begin{array}{l}\text { S10a, c } \\
\text { S10d }\end{array}$} \\
\hline$<2.0$ & feeding position maintained, mantle tissue increasingly swollen. & \\
\hline$<1.0$ & as above. One juvenile died at DO $0.8 \mathrm{mLL}^{-1}$. & \\
\hline$<0.5$ & $\begin{array}{l}\text { peak mantle tissue swelling ( } 20 \%) \text {, first individuals showed tissue retraction. Second individual died at } \\
\text { DO } 0.2 \mathrm{mLL}^{-1} \text {. }\end{array}$ & S10e \\
\hline 0 & $\begin{array}{l}\text { wide shell gape }(60 \%) \text { and strongly retracted mantle tissue }(64 \%) \text {. Three individuals died after } 14 \text { to } \\
\left.31.7 \mathrm{~h} \text { of anoxia (median } \mathrm{H}_{2} \mathrm{~S} 13.7 \mu \mathrm{M}\right) \text {, two others survived } 19.1 \text { and } 22.9 \mathrm{~h} \text { of anoxia (final } \mathrm{H}_{2} \mathrm{~S} 19.3 \\
\text { and } 5.2 \mu \mathrm{M} \text {, respectively). }\end{array}$ & S10b \\
\hline \multicolumn{3}{|c|}{ Corbula gibba (Olivi, 1792), $N=37$} \\
\hline$\geq 2.0$ & $\begin{array}{l}\text { animals started to appear on surface at lower boundary of normoxia category }(11 \%) \text { and showed peak } \\
\text { minor and major horizontal movement (total horizontal locomotion } 43 \%) \text {. }\end{array}$ & \multirow[t]{5}{*}{ S11a, b } \\
\hline$<2.0$ & number of animals appearing at the surface increased, with significant decrease in horizontal locomotion. & \\
\hline$<1.0$ & overall number of individuals increased, but some reburied or moved under bioherms. & \\
\hline$<0.5$ & number of animals unchanged. & \\
\hline 0 & $\begin{array}{l}\text { highest number of individuals on surface, no horizontal movement. One individual manipulated by hermit } \\
\text { crab Paguristes eremita but then reburied itself (no predation/scavenging). Another individual raised from } \\
\text { sediment surface by emerging infaunal sea urchin (Schizaster canaliferus). All animals survived (max. } \\
\text { anoxia duration } 78.3 \mathrm{~h} \text {; max. } \mathrm{H}_{2} \mathrm{~S} 124.5 \mu \mathrm{M} \text { ). }\end{array}$ & \\
\hline \multicolumn{3}{|c|}{ Venerupis cf. rhomboides, $N=1$} \\
\hline$\geq 2.0-<1.0$ & not visible. & \multirow{3}{*}{$\mathrm{S} 12 \mathrm{c}, \mathrm{a}, \mathrm{b}$} \\
\hline$<0.5$ & $\begin{array}{l}\text { first the sediment bulged, the siphon became visible and finally the whole animal emerged. Siphon always } \\
\text { visible, foot only occasionally, with peak horizontal locomotion (total } 15 \% \text { ). }\end{array}$ & \\
\hline 0 & $\begin{array}{l}\text { strong siphon vs. foot visibility points to greater energy investment in seeking more oxygenated water } \\
\text { than in locomotion. Mortality after } 24.5 \mathrm{~h} \text { anoxia }\left(\mathrm{H}_{2} \mathrm{~S} 111.4 \mu \mathrm{M}\right) \text {. }\end{array}$ & \\
\hline
\end{tabular}

greatest number of involved individuals was recorded during severe hypoxia (19\% of observations, Fig. 4a).

The search for better oxygen conditions led to atypical aggregations atop the highest substrates. This reduced the safety distance between species and outweighed normal inter- and interspecific aggression. The predatory crab $P$. spinifer, for example, is solitary and highly territorial. The absence of brittle stars on a multi-species clump typically indicates a resident crab (Wurzian, 1977). During normoxia, all encounters of two $P$. spinifer or of $P$. spinifer with other crabs (i.e. Macropodia spp.) ended with the dominant individual chasing the subordinate one away. This behaviour ceased at severe hypoxia: Pilumnus specimens were observed close to each other and with heterospecifics without showing any signs of aggressiveness.

\subsubsection{Predator-prey interactions}

With ongoing hypoxic stress, common anti-predator strategies such as hiding in multi-species clumps, camouflage, or escape response, ceased. The shrimp Alpheus glaber, for example, is a common prey item for both fish and other decapod crustaceans (Rufino et al., 2006). At severe hypoxia, one Alpheus specimen was closely watched by the fish Gobius niger for $1 \mathrm{~h}$ from less than $5 \mathrm{~cm}$ distance. Were it not for the chamber's plexiglass wall, the fish would no doubt have consumed the shrimp, which was clearly unable to flee. After leaving the burrow, the shrimps also had several encounters with an already motionless $P$. eremita: for up to 12 minutes both decapods remained side by side, the body of Alpheus touching the claws of Paguristes. Similarly, the brittle star O. quinquemaculata or the porcellanid crab P. longimana no longer showed escape reactions but aggregated atop bioherms together with potential predators: neither $P$. spinifer 
Table 5. Polychaeta. Protula tubularia: solitary tubeworm in calcareous tubes on hard substrate, head with two sets of red, slightly spiralled pinnate tentacles.

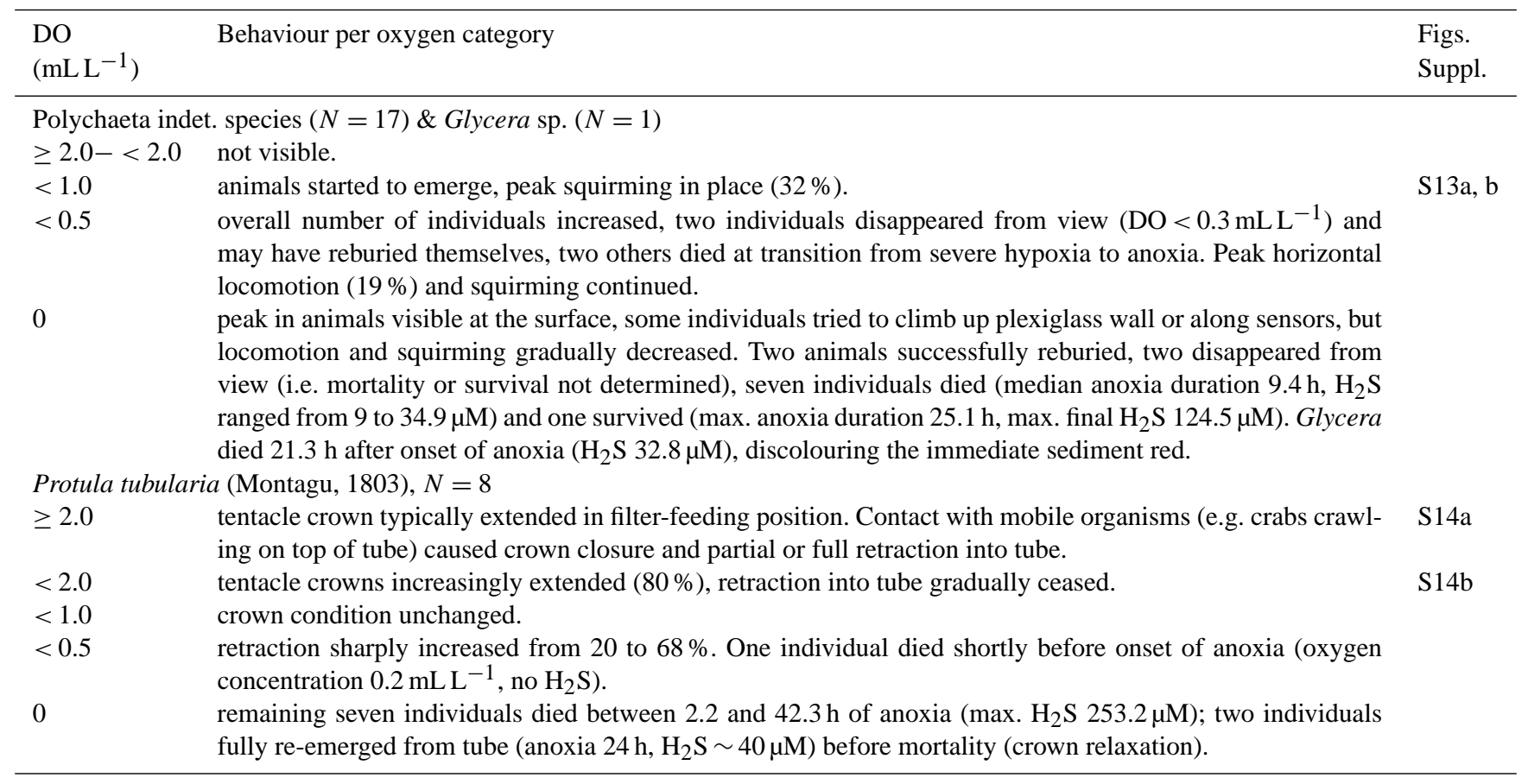

nor E. tuberosa, for example, attacked the brittle stars. In these cases, the search for more oxygenated substrates by both predator and prey species - with similar hypoxia tolerance - apparently impeded potential predation events. In the case of dissimilar tolerances, more tolerant species benefited by taking advantage of prey that were more vulnerable.

Overall, 8 predatory interactions (plus one predatory attack) were observed during the 11 deployments. These involved two sea anemone species, Cereus pedunculatus and Calliactis parasitica, and, on the prey side, six epifaunal brittle stars Ophiothrix quinquemaculata, one infaunal brittle star Ophiura spp., and one decorator crab Ethusa mascarone. Riedel et al. (2008a) describes five predatory interactions (O. quinquemaculata) in detail. The other feeding events recorded later in the study support those previous findings.

All predatory interactions occurred within a relatively narrow oxygen concentration window, at the transition from severe hypoxia to anoxia $\left(\mathrm{H}_{2} \mathrm{~S}\right.$ concentration maximum $3.5 \mu \mathrm{M})$. At this time, the anemones showed a burst in activity, i.e. extension and body rotation in all directions. In contrast, the predated organisms were already in a moribund state and/or no longer showed escape reactions. $O$. quinquemaculata, for example, generally maintained a safety distance of at least 1 to $2 \mathrm{~cm}$ from nearby anemones under normal oxygen concentrations. If contact was made, the brittle stars immediately retracted their arms and quickly moved a few centimetres away. At the time of predation, however, most brittle stars (O. quinquemaculata, Ophiura spp.) were already moribund, either clinging to bioherms or lying on the sediment. Here, the feeding interaction involved three phases: feeding (contact, pulling in of organism, transfer to mouth and ingestion), digestion, and regurgitation of brittle star remains (the latter observed 3 times). The feeding process lasted 1.7 to $7.7 \mathrm{~h}$; regurgitation (digestion 2.1 to $12.6 \mathrm{~h}$ ) took maximally $60 \mathrm{~min}$. The predatory event involving the sea anemone $C$. pedunculatus and an $O$. quinquemaculata individual (Fig. 5a-e) can also be watched in the video http://phaidra.univie.ac.at/o:87923: at second 32, the extended sea anemone (centre top) touches the arm of the moribund brittle star on the sediment and pulls the ophiuroid in. The mucus-covered remains (disc and attached arm stubs) are regurgitated at second 44 .

Finally, one highly extended and rotating C. pedunculatus made contact with an emerged Ophiura $1.7 \mathrm{~h}$ after onset of anoxia (no $\mathrm{H}_{2} \mathrm{~S}$ ). The brittle star was attached to the anemone's tentacle crown for $36 \mathrm{~min}$ before it fell on the sediment with all arms fragmented. It moved on the surface a few centimetres by "rolling" from the aboral to the oral side; $4.1 \mathrm{~h}$ after the predatory attack, only weak arm movement was recognisable. The animal died $4.6 \mathrm{~h}$ later $\left(\mathrm{H}_{2} \mathrm{~S} 2.8 \mu \mathrm{M}\right)$.

Another example for reduced responsiveness to predation risk is Ethusa mascarone (Fig. 5f, g). The crab, which shortly before discarded its protective camouflage, moved directly towards the widely opened tentacle crown of $C$. parasitica and was eaten $\left(0.4 \mathrm{~mL} \mathrm{DO} \mathrm{L}^{-1}\right.$, no $\left.\mathrm{H}_{2} \mathrm{~S}\right) .8 .3 \mathrm{~h}$ later, the anemone regurgitated part of the crab; another $4.2 \mathrm{~h}$ later the 
Table 6. Crustacea. Alpheus glaber: small deposit feeding pistol shrimp inhabiting burrows in sediment; predated mainly by fish and larger decapods, i.e. Nephrops norvegicus. Ebalia tuberosa: cryptic, night-active crab, temporarily buried in sediment, with anteriormost carapace tip protruding. Diet: mainly small annelids and crustaceans but also dead and moribund organisms. Ethusa mascarone: crab with camouflaged carapace, typically bivalve shells and living sponges, held by last pereopod pairs. Can bury itself to hide from demersal fish. Eurynome aspera: decorator crab with attached algae, sponges etc. Galathea spp.: small, cryptic squat lobsters on bioherms; primarily night-active. Inachus sp.: spider crab with attached sponges initially hid under tentacles of sea anemone $C$. pedunculatus. Macropodia spp.: the seven studied decorator crabs were rarely camouflaged (if so, then with sponges). Nepinnotheres pinnotheres: small parasitic pea crab, in this study two females inhabiting ascidians (Microcosmus spp.). Paguristes eremita: abundant hermit crab in this community; highly mobile, day-active omnivore preferring juvenile macrofauna and typically carrying numerous symbionts. Pilumnus spinifer: territorial, cryptic crab in spongedominated bioherms; night-active. Diet: juvenile macroepibenthos but also other crabs (i.e. P. longimana) or brittle stars. Pisidia longimana: small porcellanid crab, most abundant decapod in bioherms; night-active; prey for P. spinifer and fish. Behavioural reactions studied on 4 large, conspicuous individuals, mortality on 150 individuals.

\begin{tabular}{|c|c|c|}
\hline $\begin{array}{l}\mathrm{DO} \\
\left(\mathrm{mLL} \mathrm{L}^{-1}\right)\end{array}$ & Behaviour per oxygen category & $\begin{array}{l}\text { Figs. } \\
\text { Suppl. }\end{array}$ \\
\hline \multicolumn{3}{|c|}{ Alpheus glaber (Olivi, 1792), $N=2$} \\
\hline$\geq 2.0$ & $\begin{array}{l}\text { images show only one burrow opening of the two pistol shrimps (probable male-female partners; } \\
\text { P. Dworschak, personal communication, } 2013) \text {. No individual visible at opening or elsewhere on sediment } \\
\text { surface. Opening visibly larger shortly before onset of hypoxia }\left(2.4 \mathrm{~mL} \mathrm{DO} \mathrm{L}^{-1}\right) \text {. }\end{array}$ & \\
\hline$<2.0$ & $\begin{array}{l}\text { hypoxic phase } 1 \text {, before intermittent oxygen peak: opening further enlarged after } 4 \mathrm{~h} \text { of hypoxia (oxygen } \\
\left.\text { concentration } 1.6 \mathrm{~mL} \mathrm{~L}^{-1}\right) \text {. Shortly before onset of moderate hypoxia }\left(1.3 \mathrm{~mL} \mathrm{DO} \mathrm{L} \mathrm{L}^{-1} \text { ), one individual partly }\right. \\
\text { visible (chelipeds and carapace). The shrimp appeared briefly in irregular intervals at the opening before } \\
\text { retreating tail-first again (i.e. when disturbed by approaching hermit crab Paguristes eremita). During re- } \\
\text { oxygenation (intermittent oxygen peak) and subsequent hypoxic phase } 2 \text {, no pistol shrimps visible. }\end{array}$ & S15a \\
\hline$<1.0$ & one individual re-appeared at opening. & \\
\hline$<0.5$ & 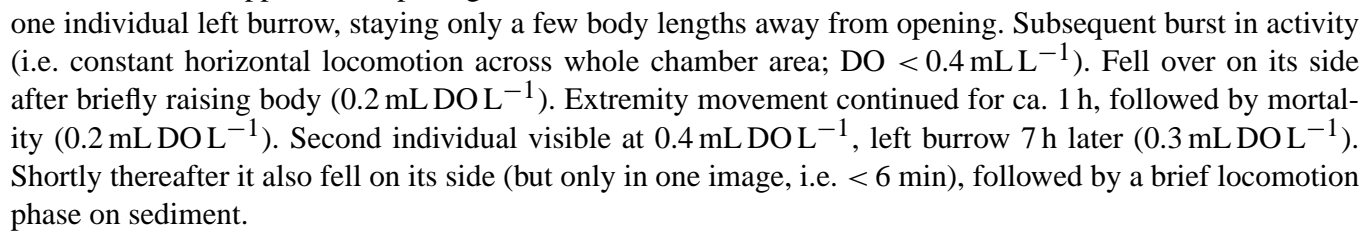 & $\mathrm{S} 15 \mathrm{~b}, \mathrm{c}$ \\
\hline 0 & $\begin{array}{l}\left.\text { after ca. } 30 \text { min anoxia }\left(\mathrm{H}_{2} \mathrm{~S} 0.6 \mu \mathrm{M}\right) \text {, second individual again fell over and died ( } 4.5 \mathrm{~h} \text { after specimen } 1\right) \text {. } \\
\text { Fragmentation visible } 6 \mathrm{~h} \text { later. }\end{array}$ & \\
\hline \multicolumn{3}{|c|}{ Ebalia tuberosa (Pennant, 1777), $N=3$} \\
\hline$\geq 2.0$ & all individuals buried in sediment, i.e. not visible. & \\
\hline$<2.0$ & first individual visible on sediment surface at $1.38 \mathrm{~mL} \mathrm{DO} \mathrm{L}^{-1}$, moving along plexiglass chamber walls. & \\
\hline$<1.0$ & $\begin{array}{l}\text { second individual emerged from sediment at } 0.63 \mathrm{~mL} \mathrm{DO} \mathrm{L}^{-1} \text {, both crabs with strong horizontal locomotion } \\
(77 \%) \text { on sediment. }\end{array}$ & S16c \\
\hline$<0.5$ & $\begin{array}{l}\text { all three individuals visible. Horizontal locomotion dropped rapidly to } 42 \% \text {, small peak in vertical loco- } \\
\text { motion as crabs start to climb onto higher/top positions on bioherms, where they remained almost inactive } \\
\text { (except for extremity movement, data not shown). }\end{array}$ & S16a, c \\
\hline 0 & $\begin{array}{l}\text { total locomotion dropped to } 10 \% \text {, while body movement peaked }(40 \%) \text {. Individuals on bioherms in } 36 \% \\
\text { of observations. Two individuals survived } 14.1 \text { and } 23.6 \mathrm{~h} \text { of anoxia and } \mathrm{H}_{2} \mathrm{~S} \text { values of } 12.8 \text { and } 19.2 \mu \mathrm{M} \text {, } \\
\text { respectively; one individual died after } 22.9 \mathrm{~h} \text { of anoxia }\left(\mathrm{H}_{2} \mathrm{~S} 16.7 \mu \mathrm{M}\right) \text {. }\end{array}$ & S16b, d, e \\
\hline \multicolumn{3}{|c|}{ Ethusa mascarone (Herbst, 1785), $N=3$} \\
\hline$\geq 2.0$ & $\begin{array}{l}\text { partly visible (i.e. including camouflage) in } 79 \% \text { of observations; "moving camouflage" on sediment surface } \\
\text { clearly indicated horizontal locomotion }(19 \%) .\end{array}$ & S17a, c \\
\hline$<2.0$ & hiding behaviour unchanged; total locomotion dropped to $13 \%$ & \\
\hline$<1.0$ & hiding behaviour unchanged; peak body movements (44\%). & S17d \\
\hline$<0.5$ & $\begin{array}{l}\text { peak total locomotion }(27 \%) \text {; all three individuals successively discarded camouflage (i.e. camouflage } \\
\text { still visible in } 66 \% \text { of observations). One individual predated by sea anemone Calliactis parasticia } \\
\left.\left(0.4 \mathrm{mLDOL} \mathrm{L}^{-1} \text {, no } \mathrm{H}_{2} \mathrm{~S}\right) \text { only } 1.3 \mathrm{~h} \text { after dropping its shell fragments (see also Sect. } 3.3 .2\right) \text {. The two other } \\
\text { individuals, discarding their camouflage at } 0.23 \text { and } 0.03 \mathrm{~mL} \mathrm{DOL} \mathrm{L}^{-1} \text {, initially hid within bioherms. }\end{array}$ & $\mathrm{S} 17 \mathrm{~b}$ \\
\hline 0 & $\begin{array}{l}\text { one individual climbed up a sensor and disappeared from view; locomotion and body movement of remaining } \\
\text { specimen nearly ceased, with mortality } 7.5 \mathrm{~h} \text { after onset of anoxia (no } \mathrm{H}_{2} \mathrm{~S} \text { ). }\end{array}$ & \\
\hline
\end{tabular}


Table 6. Continued.

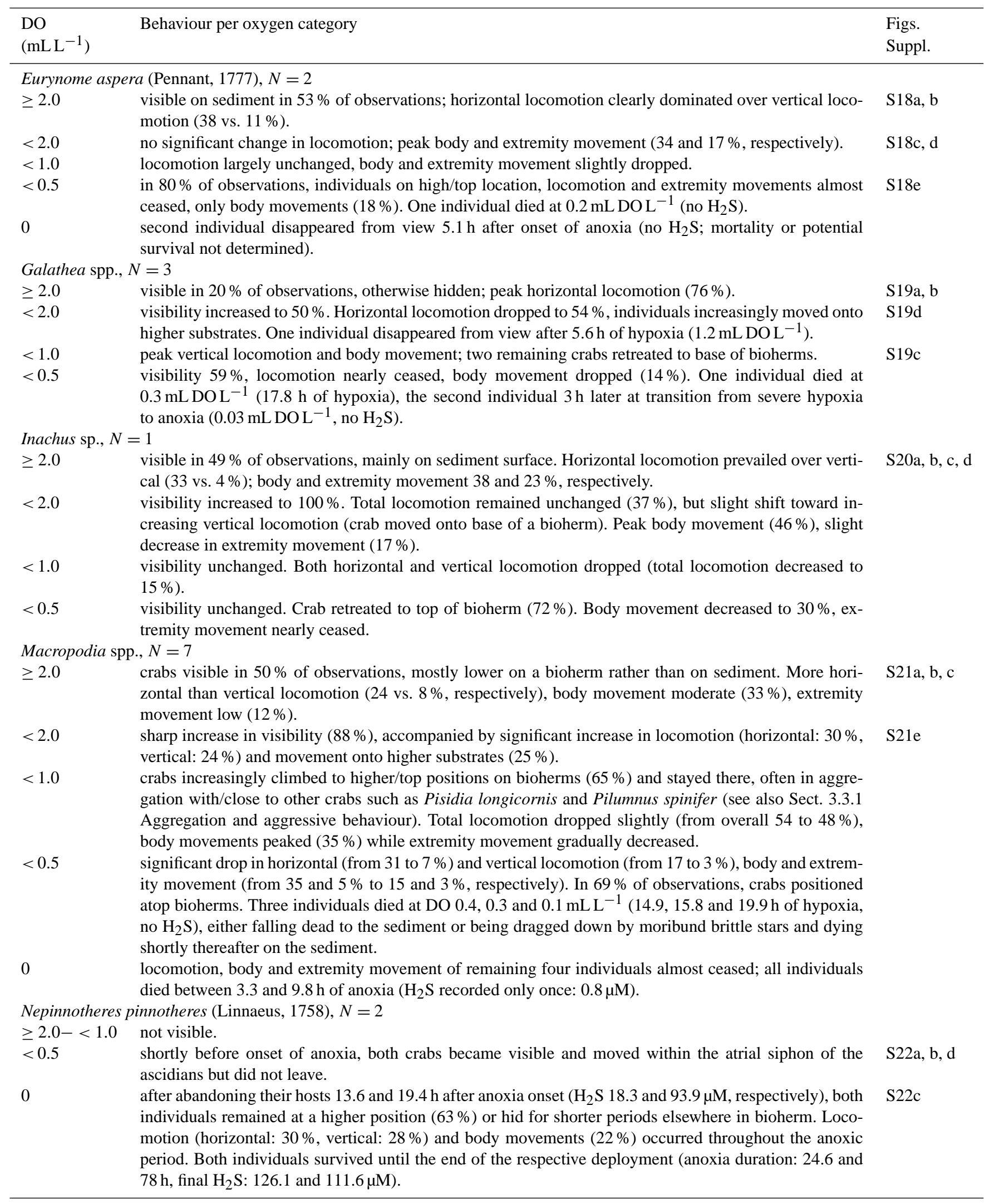


Table 6. Continued.

\begin{tabular}{|c|c|c|}
\hline $\begin{array}{l}\mathrm{DO} \\
\left(\mathrm{mLL} \mathrm{L}^{-1}\right)\end{array}$ & Behaviour per oxygen category & $\begin{array}{l}\text { Figs. } \\
\text { Suppl. }\end{array}$ \\
\hline \multicolumn{3}{|c|}{ Paguristes eremita (Linnaeus, 1767), $N=25$} \\
\hline$\geq 2.0$ & $\begin{array}{l}\text { mainly on sediment or partly hidden under multi-species clumps. Shells oriented with aperture facing } \\
\text { down, crabs only partially protruding from shell (except during intra- and interspecific interactions). } \\
\text { More locomotion during day than at night (for details on circadian rhythm see Pretterebner et al., 2012). }\end{array}$ & \\
\hline$<2.0$ & $\begin{array}{l}\text { locomotion dropped from } 23 \text { to } 14 \% \text { and the day and night rhythm dampened. The crabs increas- } \\
\text { ingly climbed onto bioherms ( } 47 \% \text { ). Body movement increased almost two-fold to } 51 \% \text {; body posture } \\
\text { changed, with single individuals starting to extend from shell. }\end{array}$ & $\mathrm{S} 23 \mathrm{~b}, \mathrm{a}, \mathrm{c}, \mathrm{d}, \mathrm{e}$, \\
\hline$<1.0$ & $\begin{array}{l}\text { number of observations with individuals on sediment and on bioherms almost equal. Body movement } \\
\text { peaked }(70 \%) \text {; extension from shell increased from } 15 \text { to } 35 \% \text {. Typical shell orientation maintained. }\end{array}$ & $\mathrm{S} 23 \mathrm{f}$ \\
\hline$<0.5$ & $\begin{array}{l}\text { some individuals moved back down to sediment, but locomotion almost ceased ( } 5 \% \text { ). Marked drop in } \\
\text { body movement (from } 70 \text { to } 40 \% \text { ). Shell orientation changed significantly, with overturned shells (aper- } \\
\text { ture facing up) in } 17 \% \text { of observations. }\end{array}$ & \\
\hline 0 & $\begin{array}{l}\text { extension from shell reached } 40 \% \text {; } 13 \text { of } 25 \text { individuals emerged from shell and walked around (sed- } \\
\text { iment, bioherms). One specimen returned to its shell but re-emerged after } 15 \text { min and finally climbed } \\
\text { on an exposed infaunal sea urchin } S . \text { canaliferus. Overall, } 9 \text { crabs died (anoxia duration: } 18.4 \text { to } 62.1 \mathrm{~h} \text {, } \\
\mathrm{H}_{2} \mathrm{~S} \text { range } 116.5 \text { to } 248 \mu \mathrm{M} \text { ), } 8 \text { of which were outside their shell on sediment. An overall } 13 \text { individuals } \\
\text { survived (maximum anoxia duration } 25.1 \mathrm{~h} ; \mathrm{H}_{2} \mathrm{~S} 124.5 \mu \mathrm{M} \text { ), } 9 \text { of which were on sediment and } 4 \text { on bio- } \\
\text { herms. Death or survival of three individuals undetermined (i.e. disappeared from view, poor visibility). }\end{array}$ & $\mathrm{S} 23 \mathrm{e}$ \\
\hline \multicolumn{3}{|c|}{ Pilumnus spinifer (H. Milne-Edwards, 1834), $N=17$} \\
\hline$\geq 2.0$ & $\begin{array}{l}\text { visibility typically reflects nighttime activity ( } 16 \% \text { of observations), with peaks in horizontal locomotion } \\
(48 \%) \text { and body movement }(26 \%) \text {. Movement mainly on sediment surface or lower on bioherms. }\end{array}$ & $\mathrm{S} 24 \mathrm{a}, \mathrm{b}, \mathrm{c}$ \\
\hline$<2.0$ & $\begin{array}{l}\text { visibility increased ( } 49 \% \text { ) because the normal day-night rhythm waned; horizontal locomotion declined } \\
\text { significantly to } 36 \% \text {, while vertical locomotion increased as individuals climbed higher up on bioherms } \\
\text { (significant increase from } 2 \text { to } 25 \% \text { ). }\end{array}$ & S24d \\
\hline$<1.0$ & $\begin{array}{l}\text { visibility further rose to } 79 \% \text {; significant increase in vertical locomotion reflected in peak values of } \\
\text { individuals atop elevated substrates }(51 \%) \text {. Intra- and interspecific aggression maintained, i.e. dominant } \\
\text { individuals chased subordinate individuals or other crabs such as Macropodia spp. away. }\end{array}$ & \\
\hline$<0.5$ & $\begin{array}{l}\text { locomotion and body movement significantly decreased, intra- and interspecific aggression ceased and } \\
\text { predator-prey relationships changed: Pilumnus no longer attacked closely adjoining prey; instead, they } \\
\text { aggregated with other individuals, for example the crab Pisidia longicornis and small invertebrates atop } \\
\text { bioherms (see also Sect. 3.3.1). Four individuals died at transition from severe hypoxia to early anoxia } \\
\text { (no } \mathrm{H}_{2} \mathrm{~S} \text { present): they turned over and fell from their elevated positions. }\end{array}$ & \\
\hline 0 & $\begin{array}{l}\text { locomotion and body movement of remaining } 13 \text { individuals almost ceased. Twelve individuals died } \\
\left.\text { (anoxia duration } 1.4 \text { to } 23.6 \mathrm{~h}, \mathrm{H}_{2} \mathrm{~S} \text { from } 0 \text { to } 72.8 \mu \mathrm{M}\right) \text {; } 1 \text { individual survived brief anoxia ( } 8.5 \mathrm{~h} \text {; no } \\
\mathrm{H}_{2} \mathrm{~S} \text { ). }\end{array}$ & \\
\hline \multicolumn{3}{|c|}{ Pisidia longimana (Risso, 1816), $N=4$} \\
\hline$\geq 2.0$ & $\begin{array}{l}\text { visible during night }(21 \%) \text { and, in } 44 \% \text { of observations, on high/top positions of bioherms. Initial high } \\
\text { locomotion (total locomotion } 76 \% \text { ) reflects nighttime activity (for details on circadian rhythm see Hasel- } \\
\text { mair et al., 2010). }\end{array}$ & S25a, d, \\
\hline$<2.0$ & $\begin{array}{l}\text { day-night rhythm waned, i.e. visibility increased (to } 37 \% \text { ); crabs located in bioherm mid-height (up to } \\
5 \mathrm{~cm} \text { above sediment, data not shown) rather than at high/top positions. }\end{array}$ & \\
\hline$<1.0$ & $\begin{array}{l}\text { daytime hiding abandoned, total locomotion dropped significantly to } 40 \% \text { (horizontal: } 30 \% \text {, vertical } \\
10 \% \text { ), whereas body movement peaked }(30 \%) \text {. }\end{array}$ & $\mathrm{S} 25 \mathrm{~b}, \mathrm{c}$ \\
\hline$<0.5$ & $\begin{array}{l}\text { increasing aggregation on high/top positions, often atop vagile fauna (e.g. Fig. } 4 \mathrm{a} \text { ) such as sea urchins or } \\
\text { the holothurian Ocnus planci. Overall, } 57 \% \text { of the individuals died at transition from severe hypoxia to } \\
\text { early anoxia (maximum } \mathrm{H}_{2} \mathrm{~S} 0.7 \mu \mathrm{M} \text { ), turning over or falling from bioherms to sediment. }\end{array}$ & \\
\hline 0 & $\begin{array}{l}\text { activity of remaining moribund } 64 \text { individuals ceased; all individuals dead after } 11.2 \mathrm{~h} \text { of anoxia, no } \\
\text { significant } \mathrm{H}_{2} \mathrm{~S} \text { concentration. }\end{array}$ & \\
\hline
\end{tabular}


Table 7. Holothuroidea. Ocnus planci: suspension-feeding holothurian commonly attached to bioherms.

\begin{tabular}{|c|c|c|}
\hline $\begin{array}{l}\text { DO } \\
\left(\mathrm{mLL}^{-1}\right)\end{array}$ & Behaviour per oxygen category & $\begin{array}{l}\text { Figs. } \\
\text { Suppl. }\end{array}$ \\
\hline \multicolumn{3}{|c|}{ Ocnus planci (Brandt, 1835), $N=4$} \\
\hline$\geq 2.0$ & $\begin{array}{l}\text { tentacle crowns mostly upward orientated and open (both } 56 \% \text { ), no tentacular movements. Otherwise, side- } \\
\text { ward/horizontal orientation and closed crown dominated ( } 43 \text { and } 40 \% \text {, respectively). }\end{array}$ & $\mathrm{S} 26 \mathrm{c}, \mathrm{b}$ \\
\hline$<2.0$ & $\begin{array}{l}\text { upward orientated crown positions peaked }(64 \%) \text {. Half-open tentacle crowns increased markedly from } 5 \text { to } \\
18 \% \text { and minor body elongation started, i.e. posterior body tapered and started to elongate }(38 \%) \text {. }\end{array}$ & S26a, e \\
\hline$<1.0$ & $\begin{array}{l}\text { significant drop in upward orientation, crowns predominantly half-open or closed ( } 24 \text { and } 42 \% \text {, respectively). } \\
\text { Minor body elongation reached } 61 \% \text {. }\end{array}$ & \\
\hline$<0.5$ & $\begin{array}{l}\text { significant increase in major body elongation }(64 \%) \text {, with total elongation peaking at } 85 \% \text {. Crowns predomi- } \\
\text { nantly side- or downward orientated ( } 51 \text { and } 23 \% \text {, respectively). }\end{array}$ & S26f \\
\hline 0 & $\begin{array}{l}\text { both downward orientation of tentacle crown and crown closure peaked ( } 56 \text { and } 65 \%) \text {. All individuals died: } \\
\text { three after ca. } 24 \mathrm{~h} \text { of anoxia }\left(\mathrm{H}_{2} \mathrm{~S} \text { range } 56.7 \text { to } 91.2 \mu \mathrm{M}\right) \text {, one individual } 48.2 \mathrm{~h} \text { after onset of anoxia. The } \\
\text { latter started to decompose ca. } 4 \mathrm{~h} \text { after death }\left(\mathrm{H}_{2} \mathrm{~S} 199 \mu \mathrm{M}\right) \text { : body started to inflate and become covered with } \\
\text { vesicles/blisters. }\end{array}$ & \\
\hline
\end{tabular}

Table 8. Echinoidea. Psammechinus microtuberculatus: epifaunal deposit-feeding sea urchin. Schizaster canaliferus: infaunal, depositfeeding echinoid; high densities in muddy Northern Adriatic soft-bottoms.

\begin{tabular}{|c|c|c|}
\hline $\begin{array}{l}\mathrm{DO} \\
\left(\mathrm{mLL}^{-1}\right)\end{array}$ & Behaviour per oxygen category & $\begin{array}{l}\text { Figs. } \\
\text { Suppl. }\end{array}$ \\
\hline \multicolumn{3}{|c|}{ Psammechinus microtuberculatus (Blainville, 1825), $N=17$} \\
\hline$\geq 2.0$ & $\begin{array}{l}\text { visible in } 54 \% \text { of observations, the remainder hidden under bioherms. All visible individuals with camouflage. } \\
\text { One individual left frame of open configuration. }\end{array}$ & $\mathrm{S} 27 \mathrm{a}, \mathrm{b}$ \\
\hline$<2.0$ & $\begin{array}{l}\text { peak visibility as animals move out from under bioherms. First individuals discard camouflage. One individual } \\
\text { returned under bioherm (not visible until end of deployment). }\end{array}$ & \\
\hline$<1.0$ & visibility decreased (three individuals hid under bioherms, not visible until end of deployment). & \\
\hline$<0.5$ & $\begin{array}{l}\text { most animals discarded their camouflage (from } 92 \text { to } 31 \% \text { ), one after being climbed upon by predatory crab } \\
\text { Pilumnus spinifer. Horizontal locomotion decreased. Eight individuals died (median DO } 0.12 \mathrm{~mL} \mathrm{~L}^{-1} \text { ). }\end{array}$ & \\
\hline 0 & $\begin{array}{l}\text { no individual was camouflaged, horizontal locomotion ceased, remaining four individuals died (median anoxia } \\
\text { duration } 5.9 \mathrm{~h} \text {, max. } \mathrm{H}_{2} \mathrm{~S} 5.6 \mu \mathrm{M} \text { ). }\end{array}$ & \\
\hline \multicolumn{3}{|c|}{ Schizaster canaliferus (Lamarck, 1816), $N=22$} \\
\hline$\geq 2.0$ & first sediment bulging visible when oxygen values approached $2 \mathrm{~mL} \mathrm{DOL}^{-1}$. & \\
\hline$<2.0$ & sediment bulging increased significantly. & S28a \\
\hline$<1.0$ & $\begin{array}{l}\text { peak sediment bulging ( } 25 \%) \text {, first animals appeared on sediment surface and peak total locomotion, whereby } \\
\text { major movements dominated. }\end{array}$ & $\mathrm{S} 28 \mathrm{~b}, \mathrm{c}, \mathrm{d}$ \\
\hline$<0.5$ & $\begin{array}{l}\text { strong increase in emerged individuals, drop in total horizontal locomotion, whereby minor movements } \\
\text { peaked. Six Schizaster died (median DO } 0.09 \mathrm{~mL} \mathrm{~L}^{-1} \text { ). }\end{array}$ & \\
\hline 0 & $\begin{array}{l}\text { peak visibility, significant drop in locomotion. Some animals flipped over and spines began to droop. Eleven } \\
\text { individuals died (median anoxia duration } 14.3 \mathrm{~h} \text {, median } \mathrm{H}_{2} \mathrm{~S} 12.9 \mu \mathrm{M} \text { ), five survived (max. } 13.9 \mathrm{~h} \text { anoxia, } \\
\text { max. final } \mathrm{H}_{2} \mathrm{~S} 11.8 \mu \mathrm{M} \text { ). }\end{array}$ & \\
\hline
\end{tabular}

remaining exoskeleton followed (anoxia duration $2.6 \mathrm{~h}, \mathrm{H}_{2} \mathrm{~S}$ $0.6 \mu \mathrm{M})$.

\subsection{Sensitivity and tolerance}

While hypoxia primarily affected behaviour and the abundance of individual species, anoxia significantly reduced the number of species. The overall number of individuals identified dropped from initially 495 at normoxia to 362 under hypoxia and ultimately to 196 , amounting to a $61 \%$ decrease in individual abundance. The corresponding decrease on the species level was from 40 to 38 at hypoxia (loss of the two decapod species Eurynome aspera: 1 individual at DO $0.2 \mathrm{mLL}^{-1}$; Galathea sp.: 2 individuals at DO 0.3 and $0.03 \mathrm{~mL} \mathrm{~L}^{-1}$; data not shown) to 24 at anoxia (overall decrease $40 \%$ ). First mortalities started at severe hypoxia: the most sensitive species was the bivalve Chlamys varia (two individuals at DO 0.8 and $0.2 \mathrm{mLL}^{-1}$ ). Mortality then increased rapidly at $<0.3 \mathrm{mLDOL}^{-1}$ and centred at the transition from severe hypoxia to early anoxia (Fig. 6). The species that began to die under hypoxia were predominantly decapods (Ethusa mascarone, Macropodia 
Table 9. Ophiuroidea. Ophiothrix quinquemaculata: this epifaunal brittle star is one of three designating species in this community. Densely aggregated on bioherms; mostly stationary with arms extending upward in typical suspension-feeding position. Ophiura spp.: ophiuroid shallowly buried in sediment. Amphiura chiajei: infaunal ophiuroid - disc and arms in mucus-maintained burrows, distal arm ends protruding.

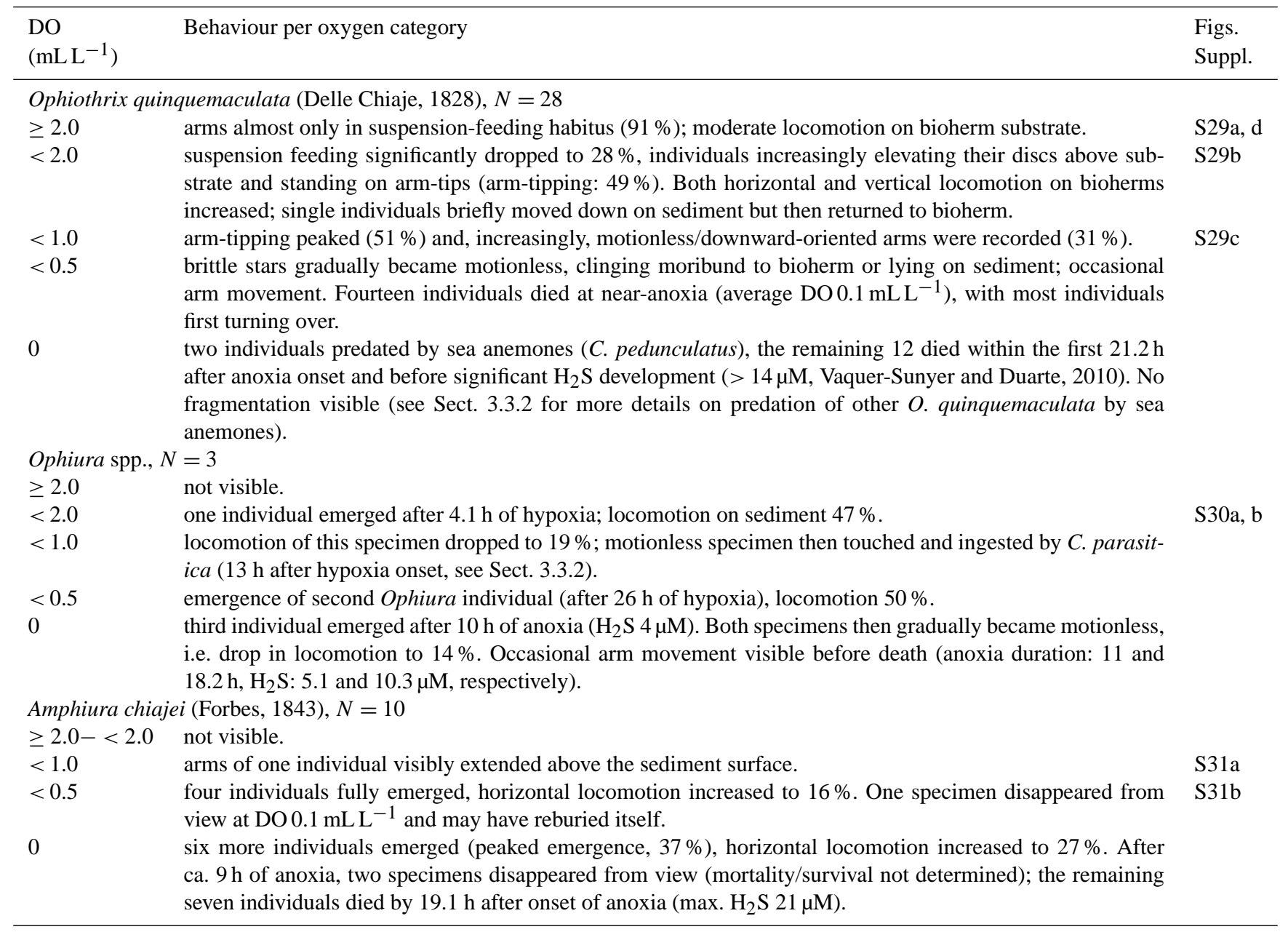

spp., Alpheus glaber, Pisidia longimana, Pilumnus spinifer) and specimens of the two echinoid species Psammechinus microtuberculatus and Schizaster canaliferus, as well as the brittle star Ophiothrix quinquemaculata. S. canaliferus was the first infaunal species to emerge and die (6 out of 17 individuals during hypoxia, median DO $0.09 \mathrm{mLL}^{-1} ; 11$ individuals during anoxia, see below). Peak mortality (94 individuals) was reached within $10 \mathrm{~h}$ of anoxia (e.g. polychaetes, mortalities ranging from 7.3 to $13.2 \mathrm{~h}$ duration of anoxia) and markedly dropped until $40 \mathrm{~h}$ of anoxia. More tolerant species (i.e. mortalities centred after $40 \mathrm{~h}$ of anoxia) included Paguristes eremita (median duration of anoxia $42.8 \mathrm{~h}$; median $\mathrm{H}_{2} \mathrm{~S} 135 \mu \mathrm{M}$ ), Hexaplex trunculus (two individuals dying at anoxia hour (h) 46.3 and 51.5, $\mathrm{H}_{2} \mathrm{~S} 117.1$ and $199.9 \mu \mathrm{M}$ ), Calliactis parasitica (median duration anoxia $52.5 \mathrm{~h}$, median $\mathrm{H}_{2} \mathrm{~S} 63 \mu \mathrm{M}$ ) and Microcosmus sulcatus (two individuals, both dying at $76.8 \mathrm{~h}$ of anoxia, $\mathrm{H}_{2} \mathrm{~S} 109.9$ and $155.3 \mu \mathrm{M}$, respectively).
The results show a differentiated sequence and range of mortality at the higher taxon level (Fig. 6). Among the most tolerant, i.e. those dying during anoxia only, were molluscs, anthozoans, and ascidians, with certain individuals surviving up to $80 \mathrm{~h}$ of anoxia and a maximum $\mathrm{H}_{2} \mathrm{~S}$ concentration of about $279 \mu \mathrm{M}$. In contrast, survival rates were lowest in polychaetes, decapods and echinoderms. Importantly, all individuals that died during hypoxia, and most of those that died during anoxia, did so before significant hydrogen sulphide development. Thus, the average $\mathrm{H}_{2} \mathrm{~S}$ concentration across all 11 deployments within the first $10 \mathrm{~h}$ of anoxia was low, i.e. $9.3 \mu \mathrm{M}$. Accordingly, 229 of the 299 mortalities (77\%) occurred before significant sulphide development. In general, species with the highest tolerance to anoxia also tolerated high sulphide values.

Overall, 196 individuals representing 24 species (8 higher taxa: Mollusca, Anthozoa, Ascidiacea, Polychaeta, Decapoda, Echinodermata, Scaphopoda) survived. In 13 
Table 10. Ascidiacea. Microcosmus spp.: solitary ascidian; major component of bioherms and designating genus in this community. Phallusia mammilata: solitary ascidian, often substrate for brittle stars and crustaceans (in this study: P. spinifer, P. longimana).

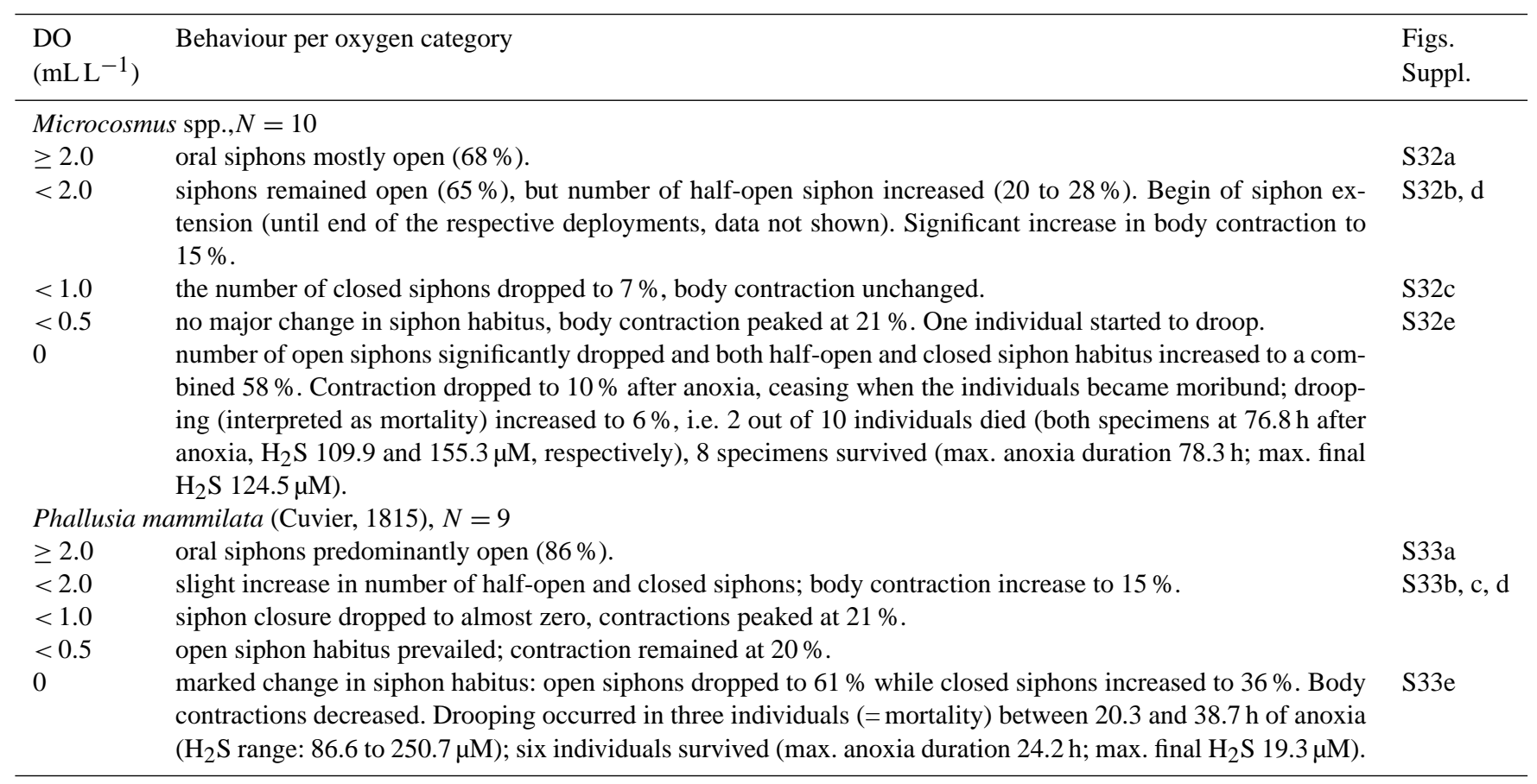

species, of which 9 are molluscs, all individuals survived. These included the pea crab Nepinnotheres pinnotheres, the sea anemone Cereus pedunculatus, the scaphopod Dentalium sp., the bivalves Corbula gibba, Nucula nucleus, Fusinus rostratus, Parvicardium papillosum, Timoclea ovata, Tellina serrata, as well as the gastropods Apporhais pes-pelecani, Murex brandaris and Nassarius cf. pygmaeus. Note, however, that based on individuals, $77 \%$ of the survivors were represented by only 2 species: the infaunal bivalve Corbula gibba (66 individuals) and the sea anemone Cereus pedunculatus (28 individuals).

Among the distinguished life habit categories (substrate relationship, mobility, feeding type), epifaunal, mobile and predator species were generally more sensitive and affected earlier (i.e. around DO $<0.2 \mathrm{~mL} \mathrm{~L}^{-1}$ ) than their infaunal, sessile, deposit and suspension-feeding conspecifics. The overall epifauna decrease was $42 \%$ (data not shown), with the cryptic fauna (i.e. the decapods E. mascarone, Galathea sp., Pisidia longimana) being particularly sensitive to decreasing oxygen (overall decrease $60 \%$ ). In contrast, in infauna the overall decrease was $36 \%$, with a major drop after $\sim 10 \mathrm{~h}$ of anoxia (e.g. S. canaliferus, indet. polychaeta, Glycera sp., Amphiura chiajei, Ophiura spp., Venerupis cf. rhomboides, Abra alba). The overall decline in mobile lifeforms was twice as high $(43 \%)$ as in sessile forms during late anoxia $(20 \%)$, i.e. $>40 \mathrm{~h}$ (mortality of $2 \mathrm{M}$. sulcatus, 4 C. parasitica, 1 Ocnus planci, 2 Protula tubularia). Finally, among the 3 major feeding types, predators (among those particularly decapods, see above) were generally most vul- nerable (overall decrease $53 \%$ ), followed by more tolerant deposit- and suspension-feeding species. In the latter 2 , overall reduction accounted for 36 and $33 \%$ (starting after $\sim 10$ and $20 \mathrm{~h}$ of anoxia), with loss in echinoderm species mainly responsible for the drop (deposit feeders: A. chiajei, Ophiura spp., P. microtuberculatus, $S$. canaliferus; suspension feeders: O. planci, O. quinquemaculata).

\section{Discussion}

The responses to hypoxia/anoxia act at various levels, and in concert, calling for a holistic, ecological approach to better understand and respond to this phenomenon. The present study emphasises two key conceptual points: benthic macrofauna behaviour as a visible, integrated tool to monitor the full range of critical oxygen thresholds in the field, and the strong potential of field studies to quantify population- and community-level endpoints. Combined, they provide a realistic basis for assessing and predicting impacts on ecological integrity.

The macrobenthos in the North Adriatic Sea reacted rapidly and successively across the entire range of declining oxygen conditions. Overall, the 11 deployments revealed a consistent and predictable pattern of reactions and phases, both within and among species (Fig. 7). Moreover, the results go beyond individual behaviours to document sequences of reactions and interactions of representative soft-bottom species. Beyond supporting and refining the 
a

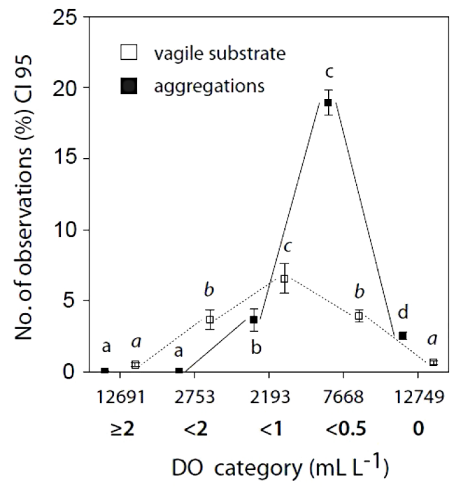

b

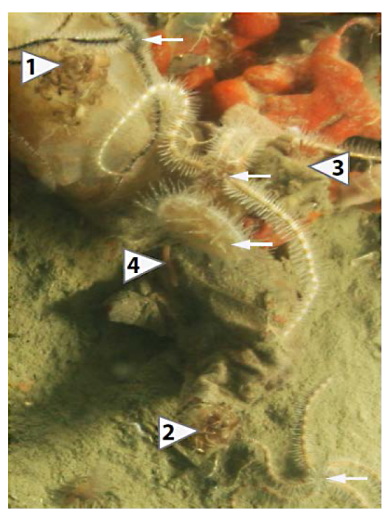

Fig. 4. (a) Mean percentage of observations of crustacean aggregations (black squares) and of investigated specimens atypically using vagile species as substrates (open squares) in the five oxygen categories. Numbers below $x$ axes: number of photographs evaluated per oxygen category. Same letters above error bars: no significant difference between means. (b) Atypical aggregations during severe hypoxia $\left(0.2 \mathrm{~mL} \mathrm{DOL} \mathrm{L}^{-1}\right.$; no $\left.\mathrm{H}_{2} \mathrm{~S}\right)$ : Numerous Pisidia longimana aggregate on the ascidians Phallusia mammilata (1) and Microcosmus spp. (2). Stressed brittle stars (Ophiothrix quinquemaculata) cling to the substrate (top arrow), one individual already moribund on sediment surface in lower right corner (bottom arrow). The hermit crab Paguristes eremita (3) with symbiotic sea anemone Calliactis parasitica (third arrow from top) on shell, on a sponge. Note O. quinquemaculata (second arrow from top) using the crab's shell as elevated substrate. Freshly emerged polychaete on ascidian (4).

reactions to hypoxia/anoxia observed elsewhere, we also report on species whose sensitivities/tolerances are poorly described (i.e. pea crabs; Stauber, 1945) or that have rarely, if ever, been continuously observed in situ (e.g. the infaunal shrimp Alpheus glaber; P. Dworschak, personal communication, 2013). Most behavioural changes and mortalities were attributable solely to oxygen depletion: $\mathrm{H}_{2} \mathrm{~S}$ had not yet developed or was present in negligible concentrations.

\subsection{Faunal responses: the individual- to community-level}

\subsubsection{Macrofauna behaviour}

The initial reactions of the infauna and epifauna differed considerably compared to behaviour under normoxia, beginning with emergence/exposure and escape/avoidance at oxygen values below $2 \mathrm{mLL}^{-1}$. This clearly identifies this oxygen concentration as a critical key threshold for Northern Adriatic communities (Fig. 7). It corresponds to values reviewed in Diaz and Rosenberg (1995) and Wu (2002) and is also in line with Vaquer-Sunyer and Duarte (2008) or Gray et al. (2002), who considered the $2 \mathrm{mg} \mathrm{DOL}^{-1}$ threshold (equivalent to $1.4 \mathrm{~mL} \mathrm{DO} \mathrm{L}^{-1}$ or $63 \mu \mathrm{M}$; e.g. Rabalais et al.,

a

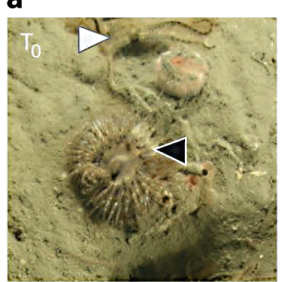

b

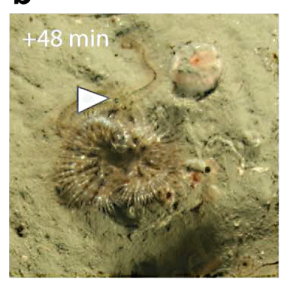

C

d

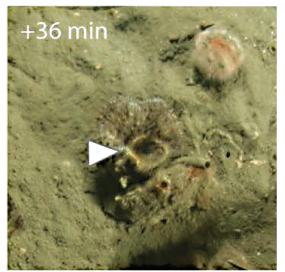

e

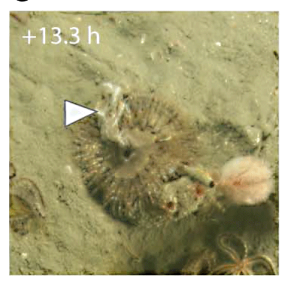

g

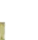

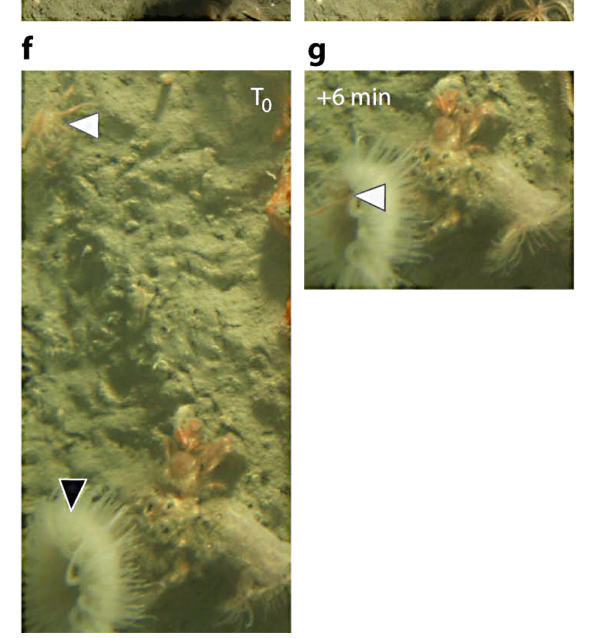
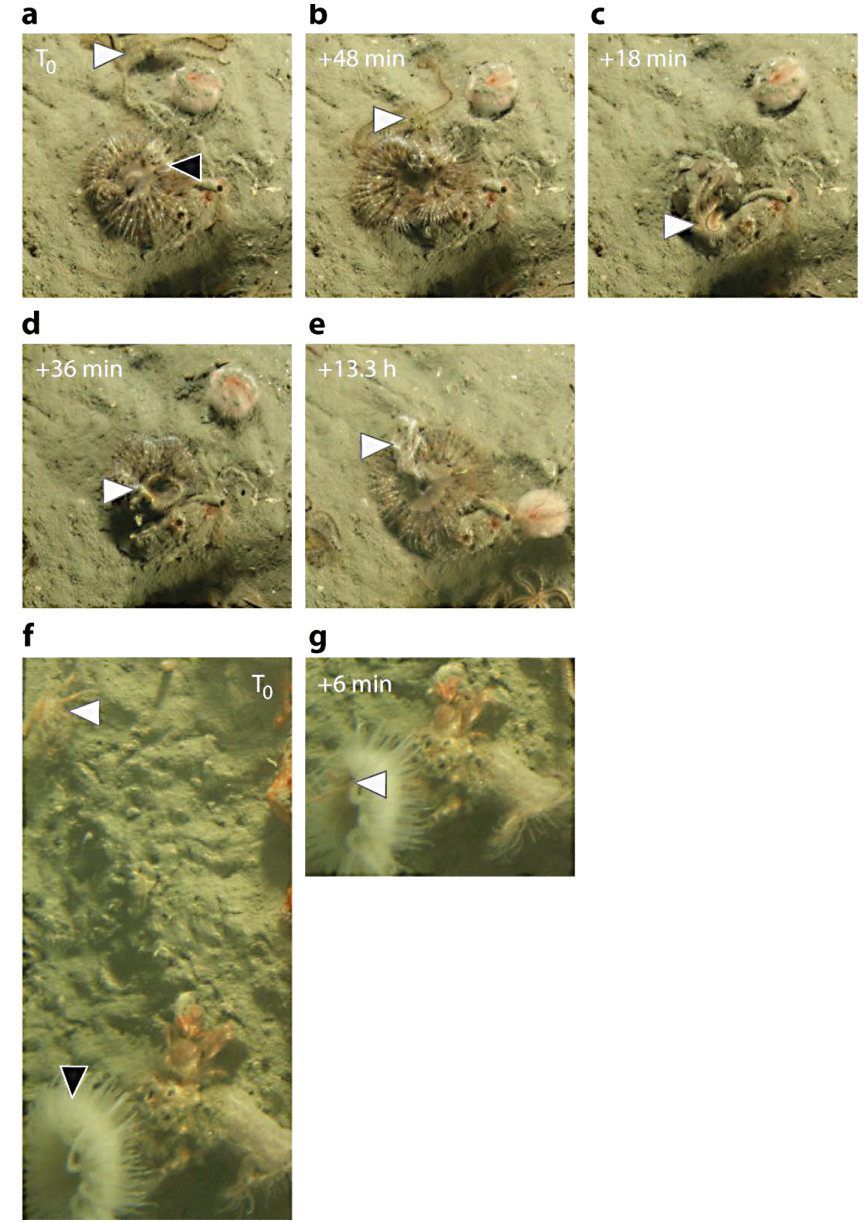
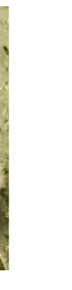

Fig. 5. Predation by Cereus pedunculatus on Ophiothrix quinquemaculata (a-e) and Calliactis parasitica on Ethusa mascarone (f-g). (a) Moribund brittle star (white arrow) on sediment, Cereus (black arrow) with elevated tentacle crown, minor extension. (b) Anemone catches the brittle star arm. (c) Brittle star pulled onto tentacle crown. (d) Prey ingested. (e) Regurgitation of remains; note still moving infaunal sea urchin Schizaster canaliferus. Video on predatory event at http://phaidra.univie.ac.at/o:87923. (f) Ethusa (white arrow), with recently discarded decoration, moving towards widely opened tentacle crown (black arrow). (g) Calliactis ingests crab, legs still protruding from mouth.

2001) as being potentially too low because certain organisms begin to react beforehand.

In this study, the onset of hypoxia triggered reactions in almost half of the species and higher taxa analysed (exceptions: nematodes, sipunculids and polychaetes). This included representatives of both the epi- and the infauna for example, the anemone Cereus pedunculatus began to extend from the sediment, the buried crab Ebalia tuberosa emerged from hiding in the sediment and the bivalve Corbula gibba appeared on the sediment surface. Also, representatives of all three major feeding types were affected: the suspension-feeding brittle star Ophiothrix quinquemaculata 
began arm-tipping, the deposit-feeding sea urchin Psammechinus microtuberculatus discarded its camouflage, and the predatory crab Pilumnus spinifer emerged from hiding places and climbed atop bioherms. These visible signs of stress render "internal" physiological adaptations (Hagerman, 1998) into "external" behavioural reactions. After exposure or emergence, the avoidance strategies aimed at increasing oxygen supply involved, initial peaks in locomotion and movement to higher, more oxygenated areas. This is because oxygen concentrations increase logarithmically with height above the bottom (Jørgensen, 1980; Diaz and Rosenberg, 1995). Accordingly, the infauna typically emerges onto the sediment surface (Nilsson and Rosenberg, 1994; Pihl et al., 1992; Hrs-Brenko et al., 1994), the epifauna climbs onto elevated substrates, and sessile species attempt to stretch upward (e.g. Baden et al., 1990; Rosenberg et al., 1991). On the flat sublittoral soft-bottoms of the Northern Adriatic Sea, hypoxia can affect several hundred to thousands of $\mathrm{km}^{2}$ (Stachowitsch, 1984). Less mobile benthic invertebrates cannot escape horizontally, potentially explaining the relatively short phase of increased activity. Multi-species clumps represent the sole refuge from short-term bottom-hypoxia. A few centimetres above the sediment surface can mean the difference between tolerable and lethal conditions. Thus, the ascidian Microcosmus sulcatus extended its siphons, paralleling observations on Molgula manhattensis by Sagasti et al. (2001). The anemone Cereus pedunculatus combined body elongation, upward tentacle extension, body rotation, swaying and contraction, probably to increase exposure to sea water both through the body wall and coelenteron, maximise the surface area to volume ratio, minimise the diffusion distance within the tissues (Sassaman and Mangum, 1972; Shick, 1991), and helping transport oxygen back to tissues attached to the bottom (Sagasti et al., 2001). Similar behaviours were observed for Calliactis parasitica (present study), for Cerianthus sp. in the Gulf of Mexico (Rabalais et al., 2001), as well as for Diadumine leucolena (Sagasti et al., 2001) and Metridium senile (Wahl, 1984) in laboratory studies. The latter two also released their pedal disc from the substrate (D. leucolena: $<1 \mathrm{mg} \mathrm{DOL}^{-1} ; M$. senile: anoxia). In our study, two $C$. parasitica individuals also detached from the hermit-crab shell at anoxia. In an earlier mortality event in the Northern Adriatic, numerous anemones - including Cerianthus sp. - were observed on the sediment surface with exposed pedal discs (e.g. Fig. 16 in Stachowitsch, 1984).

We interpret several subsequent behaviours as strategies to decrease oxygen demand once emergence, increased locomotion or climbing upwards fail. While covering the body with shells, stones or algae provides antipredator benefits or protection from desiccation and UV-radiation (e.g. Dumont et al., 2007; Hultgren et al., 2008), establishing and maintaining this camouflage can also be costly (Berke and Woodin, 2008). Thus, discarding of camouflage by sea urchins and crabs (P. microtuberculatus and Ethusa mascarone) may represent a cost-benefit trade-off in favour of losing "additional

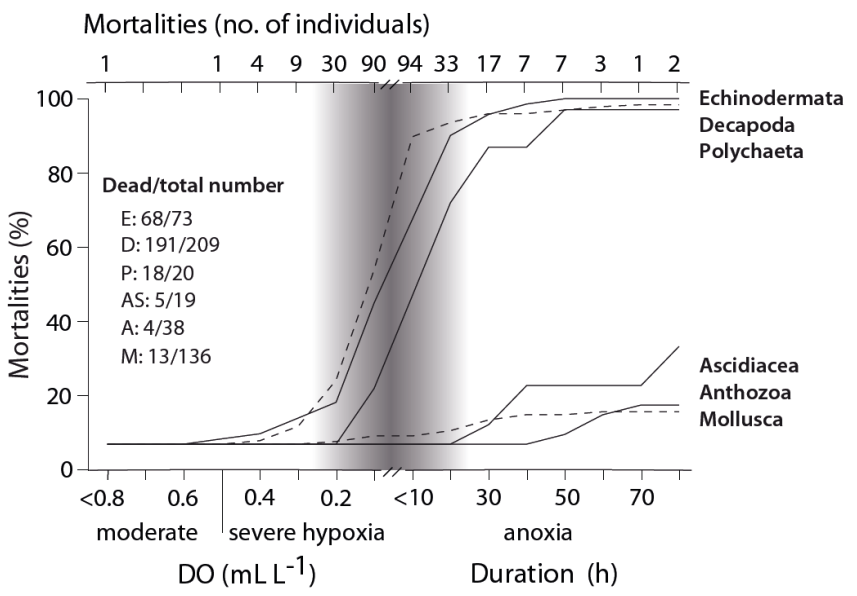

Fig. 6. Number of individuals dying $(N=299)$ across hypoxia $(\mathrm{mL}$ dissolved oxygen $[\mathrm{DO}] \mathrm{L}^{-1}$ ) and anoxia duration (h) and mortality curves of higher taxa $(\%)$ in all deployments. Rapid increase, peak and decrease in mortalities at transition from severe hypoxia to anoxia highlighted. Elongated vertical line on first $x$ axis separates moderate and severe hypoxia.

ballast" during ongoing environmental stress (Dumont et al., 2007). Similarly, the hermit crab Paguristes eremita emerged from their shells and moved about fully exposed. This was first observed here by Stachowitsch (1984) and is outlined in greater detail in Pretterebner et al. (2012).

The responses of macrofauna in one system can support interpretations of benthic health elsewhere, even across large geographical and bathymetric ranges. Thus, laboratory and field observations underline the similarity of key macrofauna responses. A case in point is arm-tipping in ophiuroids, whereby the disc and respiratory structures are raised above the sediment surface. The same posture has been observed for Amphiura chiajei, A. filiformis, and Ophiura albida in the Kattegat (Baden et al., 1990; Rosenberg et al., 1991; Vistisen and Vismann, 1997), Ophiura texturata in the North Sea (Dethlefsen and von Westernhagen, 1983), Ophiothrix quinquemaculata in the Northern Adriatic (Stachowitsch, 1984, and the present study), Ophiura sp. in the Lower St. Lawrence Estuary, Canada (Belley et al., 2010), and brittle stars in the Gulf of Mexico (Rabalais et al., 2001). This would be a new and intriguing extension of the early concept of "parallel level-bottom communities" (Thorson, 1957). Thus, the tiered behavioural shifts we have documented can help draw conclusions about future oxygen conditions and community status - early-, mid-, late-term perturbation and successive community/ecosystem degradation - both in the Northern Adriatic and elsewhere. 


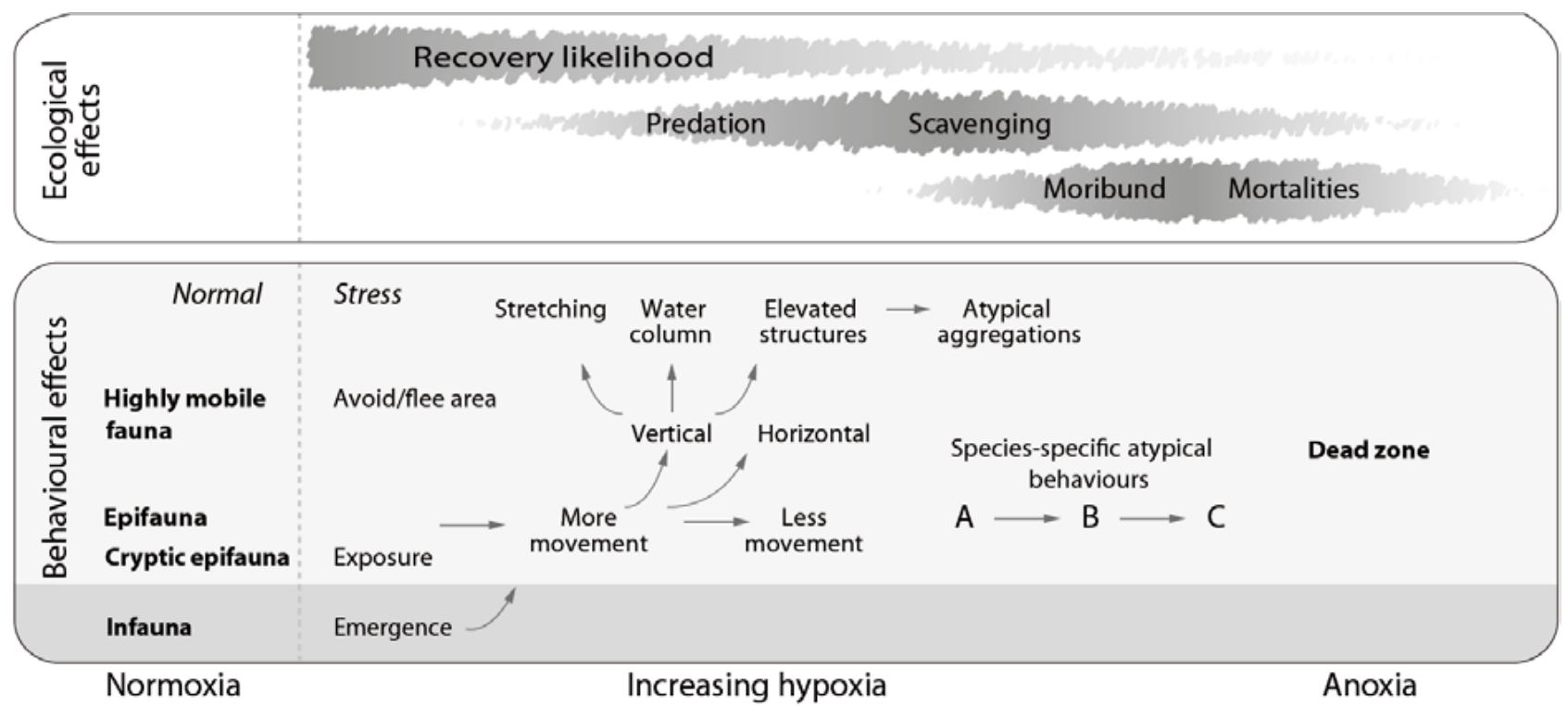

Fig. 7. Synthesis of behavioural reactions and accompanying ecological effects. See text for examples of each response category.

\subsubsection{Intra- and interspecific interactions}

Community-level changes emerge from processes operating at the individual level that trigger cascading direct and indirect effects (O'Gorman et al., 2011). Weakened or altered functionally important biological interactions, such as predator-prey dynamics, can derail community dynamics long before extensive mortalities occur (Brante and Hughes, 2001; Tallqvist, 2001; Seitz et al., 2003). Hypoxia-induced change - shifts in spatial distribution on the sediment or atop elevated substrates or abandoned defensive strategies such as decoration - adversely affect survival by increasing the vulnerability to predation. Thus, extended siphons or palps of bivalves and polychaetes above the sediment surface can be bitten off by predators (Sandberg et al., 1996). The relative tolerance of predator and prey governs predation efficiency (Breitburg et al., 1994). Nesterlode and Diaz (1998) hypothesised that relative tolerance may lead to selective predation, whereby the most sensitive prey will be exploited (Sandberg, 1994). In our experiments, the more hypoxia-tolerant sea anemones consumed moribund brittle stars (Ophiothrix quinquemaculata) and stressed decorator crabs (Ethusa mascarone). We attribute this to the predators' increased activity and radius of activity (elongation and rotation in all directions), to the prey's reduced escape reaction, and to the chemical stimuli released by moribund, damaged and/or dead individuals that initiate a foraging response in most cnidarians (Elliott and Cook, 1989; McFarlane and Lawn, 1991). Chintiroglou and Koukouras $(1991,1992)$, who studied the diet of Calliactis parasitica and Cereus pedunculatus, never identified brittle stars (or other echinoderms) as prey items, perhaps due to high handling and assimilation time and low energy content (Thayer et al., 1973). Nonetheless, the time slot for such alternate predation is relatively narrow - at the transition from severe hypoxia to anoxia. Munari and Mistri (2011) studied the effect of short-term hypoxia on predation by the muricid gastropod Rapana venosa (hypoxiatolerant) on three bivalve species with different tolerances: prey species were switched during hypoxia from the tolerant Scapharca inaequivalvis to the less tolerant and therefore more easily-to-catch (decreased burial depth and siphon extension) Tapes philippinarum.

Mutual interference and agonistic behaviour or cooperative foraging between predator species during perturbation can also alter consumption rates and prey density (Taylor and Eggleston, 2000). The present study revealed a new facet: the aggregation of potential predator-prey partners atop multispecies clumps clearly negated safety distances within and between species. Thus, oxygen deficiency outweighed normal intra- and interspecific aggression: the territory crab Pilumnus spinifer aggregated with con-/heterospecifics (see also Haselmair et al., 2010) and did not react to its normal prey (juvenile brittle stars or smaller crabs; Wurzian, 1977). We attribute this largely to the relatively similar hypoxia tolerance of crustaceans and echinoderms (i.e. Sunyer-Vaquer and Duarte, 2008), represented here by $P$. spinifer and O. quinquemaculata (see also Riedel et al., 2012). The fact that crustaceans compensate for short-term hypoxia by increasing ventilation at the expense of other energetically demanding activities such as locomotion and feeding (Taylor et al., 1977) may also play a role. Thus, by changing behaviour, hypoxia can alter trophic pathways and derail community dynamics. 


\subsubsection{Sensitivity and tolerance}

Beyond disrupting life cycles, altering behaviour and changing biological interactions, hypoxia significantly reduces abundance, biomass and diversity (e.g. Diaz and Rosenberg, 1995; Levin et al., 2009). Generally, fish are considered to be the most hypoxia-sensitive group, followed by crustaceans, polychaetes, echinoderms, sea anemones, molluscs, hydro-/scyphozoans and ascidians (Gray et al., 2002; Vaquer-Sunyer and Duarte, 2008). Our results broadly confirmed this pattern, with ascidians, anthozoans and molluscs being distinctly more tolerant than polychaetes, decapods, and echinoderms. Our in situ approach, however, provided a more nuanced picture by highlighting the complex intra- and interspecific variability in sensitivity, for example immediate behavioural reactions versus survival/mortality. The generally more tolerant molluscs (metabolic depression and energy utilisation; Larade and Storey, 2002) represented 13 of the 24 species with surviving individuals (see also Riedel et al., 2012). Nonetheless, some molluscs reacted immediately (e.g. the infaunal bivalve Corbula gibba emerging from the sediment at the onset of hypoxia), others died early (Chlamys varia and Diodora sp. at moderate and severe hypoxia), whereas others showed high survival rates (Hexaplex trunculus). Some species showed broader intraspecific tolerance. The hermit crab P. eremita tolerated between 18 and $62 \mathrm{~h}$ of anoxia. The infaunal sea urchin Schizaster canaliferus suffered 6 mortalities at hypoxia, starting at $0.3 \mathrm{mLDOL}^{-1}$, whereas 11 other individuals died within the first $24 \mathrm{~h}$ of anoxia. Such intraspecific ranges probably reflect different weight, size or life stage (e.g. Breitburg, 1992; Shimps et al., 2005) and ability to seek refuge atop elevated substrates. In later mortalities, $\mathrm{H}_{2} \mathrm{~S}$ development might also play a role. Such variability can provide an evolutionary advantage by buffering the population against stochastic, extreme events (e.g. Denny et al., 2011). Finally, the data also showed that high sensitivity and high tolerance are not necessarily mutually exclusive. Corbula gibba is a case in point: it was among the first to react to hypoxia, but by closing its valves hermetically and lowering its metabolism, it also withstood prolonged anoxia and sulfidic conditions (Hrs-Brenko, 2006 and references therein): all specimens survived our deployments.

The mortality peak at the transition from severe hypoxia to anoxia suggests that weak or short-term hypoxia (i.e. 1 to 2 days) primarily involves quantitative losses - in the sense of punctuated, species-specific mortalities - rather than fundamentally altered overall community structure and composition. Longer-lasting or more intense oxygen depletion, however, depauperises and taxonomically and functionally homogenises the benthic community (Sala and Knowlton, 2006). The fact that most mortalities took place before significant $\mathrm{H}_{2} \mathrm{~S}$ development allowed a clear distinction of the roles played by hypoxia and $\mathrm{H}_{2} \mathrm{~S}$ : low oxygen conditions alone are sufficient to cause quick and widespread community collapse in the Northern Adriatic. In a worst-case scenario, the macrofauna is eliminated entirely (Fedra et al., 1976; Stachowitsch, 1984; Hrs-Brenko et al., 1994).

Notable was the marked decrease in bottom-water $\mathrm{pH}$ from originally 8.2 to a mean of 7.8 (minimum 7.5) after ca. 4 days of incubation. Organisms exposed to hypoxia are commonly confronted simultaneously with acidification (hypercapnia) stress, for example, respiration reduces oxygen, leads to elevated carbon dioxide $\left(\mathrm{CO}_{2}\right)$ levels in the water and lowers the $\mathrm{pH}$, thereby causing a significant acidosis in tissues (e.g. Burnett and Stickle, 2001). Melzner et al. (2013) recently illustrated that hypoxic coastal areas are already characterised by $\mathrm{CO}_{2}$ partial pressure $\left(p \mathrm{CO}_{2}\right)$ values that will probably not be reached by ocean acidification in the surface ocean in the next few hundred years (i.e. depending on salinity, > 1700-3200 $\mu \mathrm{atm}$ ), with the potential for a 50 to $100 \%$ increase within this century. We cannot assess the hypercapnic stress on the vulnerability of the benthic macrofauna in the present study. During future climate change, however, the simultaneous shifts in temperature, $\mathrm{CO}_{2}$, and hypoxia levels will markedly increase the sensitivity to environmental extremes relative to a change in just one of these parameters (Pörtner et al., 2005).

Note that while the bioherms markedly increase habitat complexity and provide refuge for mobile species, they also potentially accelerate mortalities and ecosystem collapse in a positive feedback loop (e.g. emergence and death of associated species from decomposing bioherms). This supports the conclusions drawn by Metzger et al. (2013, this issue) that the input of organic material by decaying macrofauna is partially responsible for the deteriorating biogeochemical environment. Accordingly, the death of major bioherm constituents such as sponges may also help define tipping points (Fig. 1). Such hypoxia-induced community degradation has also been observed in other biogenic habitats (e.g. oyster beds, Lenihan and Peterson, 1998): domino effects lead to widespread ecosystem degradation (Lenihan et al., 2001).

Beyond extending and complementing earlier field observations (e.g. Jørgensen, 1980; Stachowitsch, 1984, Rabalais et al., 2001), recent reviews (e.g. Levin et al., 2009) and meta-analyses (e.g. Vaquer-Sunyer and Duarte, 2008), the detailed sensitivities and tolerances can provide insight into post-disturbance community compositions. Thus, coupled with additional information (e.g. on growth rates and immigration), the data can help interpret and reconstruct the severity and timing of past oxygen depletion events based on the composition and sizes of remaining species.

\subsection{Biodiversity and ecosystem functioning: the ecological perspective}

Diversity loss due to oxygen depletion is determined by multiple factors, ranging from sensitivity to low DO, to the presence of additional stressors (e.g. Vaquer-Sunyer and Duarte, 2010, 2011). The multiple interactions and feedbacks, hidden drivers and emergent properties complicate predicting 
the consequences of species loss for ecosystem function. One assumption has been that high diversity maintains a high complexity of interactions and feedbacks among species, supporting stability and resistance to disturbance (Cardinale et al., 2012). In the case of bioherms and anoxia, however, multi-tiered complexity may actually accelerate community collapse (see above). Moreover, most key ecosystem processes are performed by particular species (Solan et al., 2004; Hector and Bagchi, 2007). Even rare species can perform key functions and increase the level of functional diversity (Mouillot et al., 2013), sustaining ecosystem processes (Tilman et al., 1997; Mouillot et al., 2011). Clearly, ecosystem performance depends on both the quantity (i.e. size/biomass) and quality (diversity) of biodiversity (Thrush et al., 2006).

Oxygen depletion triggered a significant drop in both individuals ("quantitative" impact on function, see below) and species ("qualitative" impact). The unique functional roles of some species (Ellison et al., 2005) become evident when examining major life habit categories (substrate relationship, mobility and feeding type). In the Northern Adriatic, suspension feeding can be used in a process-orientated interpretation of ecosystem status. Particular species typically filter a certain range of particle sizes (e.g. Ward and Shumway 2004). When some individuals of that species are missing, other individuals continue to feed on that particle size (quantitative loss of function). When, however, the species itself is lost, then that particle size range may no longer be filtered (qualitative loss). The relatively early loss of hypoxiasensitive sponges and brittle stars (O. quinquemaculata), but survival of the more tolerant ascidian Microcosmus sulcatus, all filtering distinct particle sizes (Gili and Coma, 1998), probably represents a qualitative shift in filter-feeding capacity. Moreover, the loss of two key suspension feeding components at the hypoxia/anoxia transition may markedly compromise the overall regulatory role of the filter-feeding compartment (natural eutrophication control; Officer et al., 1982). Loss of the stabilising role of the ORM community the benthos converts pelagic into benthic biomass and serves as a storage compartment (Ott and Fedra, 1977) - no doubt significantly impacts long-term and large-scale ecosystem functioning.

Importantly, the impact on ecosystem integrity begins much earlier, long before such functionally important components are missing entirely (e.g. Thrush and Dayton, 2002). Here, behaviour is a sentinel. From the suspension-feeding perspective, the change from $O$. quinquemaculata's feeding posture to arm-tipping at mild hypoxia affects benthicpelagic coupling (Graf, 1992) long before the animals die. From the bioturbation perspective, the upward movement (i.e. sediment bulging, Fig. 3) and emergence of the infaunal sea urchin Schizaster canaliferus means that particle reworking and burrow ventilation (Schinner et al., 1993; Kristensen et al., 2012) cease long before mortality.
In the Northern Adriatic, the complex bioherms create distinct "biodiversity hotspots" that provide substrate for larval settlement and epigrowth, shelter and food on the structurally less complex soft-bottom surfaces. The rapid mortality of their long-lived and slow-growing component species, such as larger sponges, stands in stark contrast to the slow recovery. The anoxic event in September 1983, for example, destroyed $50 \%$ of the epifaunal biomass in only 2 days, and over $90 \%$ within 4 days (Stachowitsch, 1984). The subsequent recolonisation process was very slow, with both total biomass and the relative contribution of key species (O. quinquemaculata, Microcosmus spp., the sponge Reniera sp.) remaining distinctly below previously recorded values for years (Stachowitsch, 1991). Additionally, benthic recovery was (and presently continues to be) further impaired by harmful fishing activities and renewed oxygen depletions (e.g. Stachowitsch and Fuchs, 1995; Kollmann and Stachowitsch, 2001). The overall result is marked longer-term community degradation and decreased habitat complexity, offering new niches for opportunistic colonisers and nonindigenous species (e.g. Jewett et al., 2005; Dumont et al., 2011).

\section{Conclusions}

Coastal oxygen depletion raises many questions, among them how these events can be detected early, how their spatial extents, durations and frequencies can be monitored, and how the effects ameliorated. This requires knowing the state of the benthic community and the ecological impacts at multiple levels, organism to ecosystem.

As an integrative parameter, behavioural reactions and mortality help define critical oxygen thresholds and determine the immediate ecological status. The knowledge about sensitive ("losers"; Roberts and Brink, 2010) and more tolerant species (surviving post-disturbance "winners") can help to pinpoint and define the spatial extension of past mortalities. Finally, the roles individual species play, help better gauge potential effects on ecosystem integrity, function and resilience.

Our integrated approach is applicable across marine communities, habitats and biogeographical zones, and could also provide input into palaeoecological interpretations. Identifying key categories of stress reactions goes beyond being a "first-aid" tool for marine biologists, technicians, divers, or fishermen. It also provides a useful approach to transport complex ecological processes to the public and decisionmakers to define specific monitoring, assessment and conservation plans. 
Supplementary material related to this article is available online at http://www.biogeosciences.net/11/ 1491/2014/bg-11-1491-2014-supplement.pdf.

Acknowledgements. The authors would like to thank two anonymous reviewers and J. Middelburg (editor) for their constructive and helpful suggestions, which we were happy to incorporate, and P. Jumars for his comment on the statistical analysis. We thank R. Machan (electronics), V. Perlinger (workshop), G. Eder (photography) and S. Maringer (chemistry), P. Steiner and I. Gallmetzer (diving), as well as A. Stargardt (help in matters large and small) for their support and many years of excellent cooperation. We are also grateful to the directors (V. Malacic, A. Malej) and staff (T. Makovec, J. Forte, G. Polajnar) at the Marine Biology Station (MBS) Piran, Slovenia, for their hospitality and support during the fieldwork. This study was financed by the Austrian Science Fund (FWF; projects P17655-B03 and P21542-B17) and supported by the OEAD Bilateral Slovenian Austrian Scientific Technical Cooperation project SI 22/2009. This paper is dedicated to the memory of Heye Rumohr, an inspriring man, dedicated mentor and great friend.

Edited by: J. Middelburg

\section{References}

Adams, S. M.: Establishing causality between environmental stressors and effects on aquatic ecosystems, Hum. Ecol. Risk Assess., 9, 17-35, 2003.

Baden, S. P., Loo, L. O., Pihl, L., and Rosenberg, R.: Effects of eutrophication on benthic communities including fish: Swedish west coast, Ambio, 19, 113-122, 1990.

Belley, R., Archambault, P., Sundby, B., Gilbert, F., and Gagnon, J.M.: Effects of hypoxia on benthic macrofauna and bioturbation in the Estuary and Gulf of St. Lawrence, Canada, Cont. Shelf Res., 30, 1302-1313, 2010.

Berke, S. K. and Woodin, S. A.: Energetic costs, ontogenetic shifts and sexual dimorphism in spider crab decoration, Funct. Ecol., 22, 1125-1133, 2008.

Biro, P. A.: Do rapid assays predict repeatability in labile (behavioural) traits?, Anim. Behav., 83, 1295-1300, 2012.

Blasnig, M., Riedel, B., Schiemer, L., Zuschin, M., and Stachowitsch, M.: Short-term post-mortality scavenging and longer term recovery after anoxia in the northern Adriatic Sea, Biogeosciences, 10, 7647-7659, doi:10.5194/bg-10-7647-2013, 2013.

Boyd, W. A., Brewer, S. K., and Williams, P. L.: Altered behavior of invertebrates living in polluted environments, in: edited by: Dell'Omo, G., 293-336, John Wiley \& Sons Ltd, Chichester, UK, 2002.

Brante, A. and Hughes, R. N.: Effect of hypoxia on the preyhanding behaviour of Carcinus maenas feeding on Mytilus edulis, Mar. Ecol.-Prog. Ser., 209, 301-305, 2001.

Breitburg, D.: Episodic hypoxia in Chesapeake Bay: Interacting effects of recruitment, behavior, and physical disturbance, Ecol. Monogr., 62, 525-546, 1992.
Breitburg, D. L., Steinberg, N., DuBeau, S., Cooksey, C., and Houde, E. D.: Effects of low dissolved oxygen on predation on estuarine fish larvae, Mar. Ecol.-Prog. Ser., 104, 235-246, 1994.

Burnett, L. E. and Stickle, W. B.: Physiological responses to hypoxia, in: Coastal Hypoxia: Consequences for Living Resources and Ecosystems, Coastal and Estuarine Studies, edited by: Rabalais, N. N. and Turner, R. E., 58, 101-114, Am. Geophys. Union, Washington DC, 2001.

Cardinale, B. J., Duffy, J. E., Gonzalez, A., Hooper, D. U., Perrings, C., Venail, P., Narwani, A., Mace, G. M., Tilman, D., Wardle, D. A., Kinzig, A. P., Daily, G. C., Loreau, M., Grace, J. B., Larigauderie, A., Srivastava, D. S., and Naeem, S.: Biodiversity loss and its impact on humanity, Nature, 486, 59-67, 2012.

Chintiroglou, C. and Koukouras, A.: Observations on the feeding habits of Calliactis parasitica (Couch, 1842), Anthozoa, Cnidaria, Oceanol. Acta, 14, 389-396, 1991.

Chintiroglou, C. and Koukouras, A.: The feeding habits of three Mediterranean sea anemone species, Anemonia viridis (Forskal), Actinia equina (Linnaeus) and Cereus pedunculatus (Pennant), Helgoländer Meeresunters., 46, 53-68, 1992.

Conley, D. J., Carstensen, J., Vaquer-Sunyer, R., and Duarte, C. M.: Ecosystem thresholds with hypoxia, Hydrobiologia, 629, 21-29, 2009.

Culp, J. M., Podemski, C. L., Cash, K. J., and Lowell, R. B.: A research strategy for using stream microcosms in ecotoxicology: integrating experiments at different levels of biological organization with field data, J. Aquat. Ecosyst. Stress Recov., 7, 167-176, 2000.

Danovaro, R., Fonda Umani, S., and Pusceddu, A.: Climate change and the potential spreading of marine mucilage and microbial pathogens in the Mediterranean Sea, PLoS ONE, 4, e7006, doi:10.1371/journal.pone.0007006, 2009.

Denny, M. W., Wesley Dowd, W., Bilir, L., and Mach, K. J.: Spreading the risk: small-scale body temperature variation among intertidal organisms and its implications for species persistence, J. Exp. Mar. Biol. Ecol., 400, 175-190, 2011.

Dethlefsen, V. and von Westernhagen, H.: Oxygen deficiency and effects on bottom fauna in the eastern German Bight, Meeresforschung, 30, 42-53, 1983.

De Troch, M., Roelofs, M., Riedel, B., and Grego, M.: Structural and functional responses of harpacticoid copepods to anoxia in the Northern Adriatic: an experimental approach, Biogeosciences, 10, 4259-4272, doi:10.5194/bg-10-4259-2013, 2013.

Diaz, R. J. and Rosenberg, R.: Marine benthic hypoxia: A review of its ecological effects and the behavioural responses of benthic macrofauna, Oceanogr. Mar. Biol. Ann. Rev., 33, 245-303, 1995.

Diaz, R. and Rosenberg, R.: Spreading dead zones and consequences for marine ecosystems, Science, 321, 926-929, 2008.

Diaz, R., Selman, M., and Chique, C.: Global eutrophic and hypoxic coastal systems, in: Eutrophication and Hypoxia: Nutrient Pollution in Coastal Waters, Washington, DC, World Resources Institute, available at: http://www.wri.org/project/eutrophication/, 2011.

Dumont, C. P., Drolet, D., Deschênes, I., and Himmelman, J. H.: Multiple factors explain the covering behaviour in the green sea urchin, Strongylocentrotus droebachiensis, Anim. Behav., 73, 979-986, 2007.

Dumont, C. P., Gaymer, C. F., and Thiel, M.: Predation contributes to invasion resistance of benthic communities against the non- 
indigenous tunicate Ciona intestinalis, Biol. Invasions, 13, 20232034, 2011.

Elliott, J. and Cook, C. B.: Diel variation in prey capture behavior by the corallimorpharian Discosoma sanctithomae: mechanical and chemical activation of feeding, Biol. Bull. (Woods Hole), 176, 218-228, 1989.

Ellison, A. M., Bank, M. S., Clinton, B. D., Colburn, E. A., Elliott, K., Ford, C. R., Foster, D. R., Kloeppel, B. D., Knoepp, J. D., Lovett, G. M., Mohan, J., Orwig, C. R., Rodenhouse, N. L., Sobczak, W. V., Stinson, K. A., Stone, J. K., Swan, C. M., Thompson, J., Von Holle, B., and Webster, J. R.: Loss of foundation species: consequences for the structure and dynamics of forested ecosystems, Front. Ecol. Environ., 3, 479-486, 2005.

Ekau, W., Auel, H., Pörtner, H.-O., and Gilbert, D.: Impacts of hypoxia on the structure and processes in pelagic communities (zooplankton, macro-invertebrates and fish), Biogeosciences, 7, 1669-1699, doi:10.5194/bg-7-1669-2010, 2010.

Fedra, K., Ölscher, E. M., Scherübel, C., Stachowitsch, M., and Wurzian, R. S.: On the ecology of a North Adriatic benthic community: distribution, standing crop and composition of the macrobenthos, Mar. Biol., 38, 129-145, 1976.

Gili, J. M. and Coma, R.: Benthic suspension feeders: their paramount role in littoral marine food webs, Trends Ecol. Evol., 13, 316-321, 1998.

Gooday, A. J., Jorissen, F., Levin, L. A., Middelburg, J. J., Naqvi, S. W. A., Rabalais, N. N., Scranton, M., and Zhang, J.: Historical records of coastal eutrophication-induced hypoxia, Biogeosciences, 6, 1707-1745, doi:10.5194/bg-6-1707-2009, 2009.

Graf, G.: Benthic-pelagic coupling: a benthic view, Oceanogr. Mar. Biol. Ann. Rev., 30, 149-190, 1992.

Gray, J. S., Wu, R. S. S., and Or, Y. Y.: Effects of hypoxia and organic enrichment on the coastal marine environment, Mar. Ecol.Prog. Ser., 238, 249-279, 2002.

Grego, M., Stachowitsch, M., De Troch, M., and Riedel, B.: CellTracker Green labelling vs. rose bengal staining: CTG wins by points in distinguishing living from dead anoxiaimpacted copepods and nematodes, Biogeosciences, 10, 45654575, doi:10.5194/bg-10-4565-2013, 2013.

Grego, M., Riedel, B., Stachowitsch, M., and De Troch, M.: Meiofauna winners and losers of coastal hypoxia: case study harpacticoid copepods, Biogeosciences, 11, 281-292, doi:10.5194/bg11-281-2014, 2014.

Grieshaber, M. K., Hardewig, I., Kreutzer, U., and Pörtner, H-O.: Physiological and metabolic responses to hypoxia in invertebrates, Rev. Physiol. Biochem. Pharmacol., 125, 43-147, 1994.

Gruber, N.: Warming up, turning sour, losing breath: ocean biogeochemistry under global change, Phil. T. Roy. Soc. A, 369, 19801996, 2011.

Hagerman, L.: Physiological flexibility; a necessity for life in anoxic and sulphidic habitats, Hydrobiologia, 375/376, 241-254, 1998.

Halpern, B. S., Walbridge, S., Selkoe, K. A., Kappel, C. V., Micheli, F., D’Agrosa, C., Bruno, J. F., Casey, K. S., Ebert, C., Fox, H. E., Fujita, R., Heinemann, D., Lenihan, H. S., Madin, E. M., Perry, M. T., Selig, E. R., Spalding, M., Steneck, R., and Watson, R.: A global map of human impact on marine ecosystems, Science, 319, 948-952, 2008.

Haselmair, A., Stachowitsch, M., Zuschin, M., and Riedel, B.: Behaviour and mortality of benthic crustaceans in response to ex- perimentally induced hypoxia and anoxia in situ, Mar. Ecol.Prog. Ser., 414, 195-208, 2010.

Hector, A. and Bagchi, R.: Biodiversity and ecosystem multifunctionality, Nature, 448, 188-190, 2007.

Hofmann, A. F., Peltzer, E. T., and Brewer, P. G.: Kinetic bottlenecks to respiratory exchange rates in the deep-sea - Part 1: Oxygen, Biogeosciences, 10, 5049-5060, doi:10.5194/bg-10-50492013, 2013.

Howarth, R., Chan, F., Conley, D. J., Garnier, J., Doney, S. C., Marino, R., Billen, G.: Coupled biogeochemical cycles: eutrophication and hypoxia in temperate estuaries and coastal marine ecosystems, Front. Ecol. Environ., 9, 18-26, 2011.

Hrs-Brenko, M.: The basket shell, Corbula gibba Olivi, 1792 (Bivalve Mollusks) as a species resistant to environmental disturbances: A review, Acta Adriat., 47, 49-64, 2006.

Hrs-Brenko, M., Medaković, D., Labura, Ž., and Zahtila, E.: Bivalve recovery after a mass mortality in the autumn of 1989 in the northern Adriatic Sea, Period. Biol., 96, 455-458, 1994.

Hultgren, K. M. and Stachowicz, J. J.: Alternative camouflage strategies mediate predation risk among closely related cooccuring kelp crabs, Oecologia, 55, 519-528, 2008.

Jewett, E. B., Hines, A. H., and Ruiz, G. M.: Epifaunal disturbance by periodic low levels of dissolved oxygen: native vs. invasive species response, Mar. Ecol.-Prog. Ser., 304, 31-44, 2005.

Jørgensen, B. B.: Seasonal oxygen depletion in the bottom waters of a Danish fjord and its effect on the benthic community, Oikos, 34, 68-76, 1980.

Keeling, R. F., Kortzinger, A., and Gruber, N.: Ocean deoxygenation in a warming world, Annu. Rev. Mar. Sci., 2, 199-229, 2010.

Kollmann, H. and Stachowitsch, M.: Long-term changes in the benthos of the Northern Adriatic Sea: a phototransect approach, P.S.Z.N.I: Mar. Ecol., 22, 135-154, 2001.

Koron, N., Ogrinc, N., Metzger, E., Riedel, B., and Faganeli, J.: Diagenesis and benthic fluxes of nutrients and metals during experimentally induced anoxia in the Gulf of Trieste (northern Adriatic Sea), Biogeosciences Discuss., 10, 11729-11755, doi:10.5194/bgd-10-11729-2013, 2013.

Kristensen, E., Penha-Lopes, G., Delefosse, M., Valdemarsen, T., Quintana, C. O., and Banta, G. T.: What is bioturbation? The need for a precise definition for fauna in aquatic sciences, Mar. Ecol.-Prog. Ser., 446, 285-302, 2012.

Langlet, D., Geslin, E., Baal, C., Metzger, E., Lejzerowicz, F., Riedel, B., Zuschin, M., Pawlowski, J., Stachowitsch, M., and Jorissen, F. J.: Foraminiferal survival after long-term in situ experimentally induced anoxia, Biogeosciences, 10, 7463-7480, doi:10.5194/bg-10-7463-2013, 2013a.

Langlet, D., Baal, C., Geslin, E., Metzger, E., Zuschin, M., Riedel, B., Risgaard-Petersen, N., Stachowitsch, M., and Jorissen, F. J.: Foraminiferal species responses to in situ experimentally induced anoxia in the Adriatic Sea, Biogeosciences Discuss., 10, 12065 12114, doi:10.5194/bgd-10-12065-2013, 2013 b.

Larade, K. and Storey, K. B.: A profile of the metabolic responses to anoxia in marine invertebrates, in: Sensing, Signaling and Cell Adaptation, edted by: Storey, J. M. and Storey, K. B., 27-36, Elsevier Science, New York, 2002.

Lenihan, H. S. and Peterson, C. H.: How habitat degradation through fishery disturbance enhances impacts of hypoxia on oyster reefs, Ecol. Appl., 8, 128-140, 1998. 
Lenihan, H. S., Peterson, C. H., Byers, J. E., Grabowski, J. H., Thayer, G. W., and Colby, D. R.: Cascading of habitat degradation: oyster reefs invaded by refuge fishes escaping stress, Ecol. Appl., 11, 764-782, 2001.

Levin, L. A., Ekau, W., Gooday, A. J., Jorissen, F., Middelburg, J. J., Naqvi, S. W. A., Neira, C., Rabalais, N. N., and Zhang, J.: Effects of natural and human-induced hypoxia on coastal benthos, Biogeosciences, 6, 2063-2098, doi:10.5194/bg-6-2063-2009, 2009.

Long, W. C. and Seitz, R. D.: Trophic interactions under stress: hypoxia enhances foraging in an estuarine food web, Mar. Ecol.Prog. Ser., 362, 59-68, 2008.

Malej, A. and Malačič, V.: Factors affecting bottom layer oxygen depletion in the Gulf of Trieste (Adriatic Sea), Annales, 7, 3342, 1995.

McFarlane, I. D. and Lawn, I. D.: The senses of sea anemones: response of the SSI nerve net to chemical and mechanical stimuli, Hydrobiologia, 216/217, 599-604, 1991.

Melzner, F., Thomsen, J., Koeve, W., Oschlies, A., Gutowska, M. A., Bange, H. W., Hansen, H. P., and Körtzinger, A.: Future ocean acidification will be amplified by hypoxia in coastal habitats, Mar. Biol., 160, 1875-1888, 2013.

Metzger, E., Langlet, D., Viollier, E., Koron, N., Riedel, B., Stachowitsch, M., Faganeli, J., Tharaud, M., Geslin, E., and Jorissen, F.: Artificially induced migration of redox layers in a coastal sediment from the Northern Adriatic, Biogeosciences Discuss., 10, 12029-12063, doi:10.5194/bgd-10-12029-2013, 2013.

Middelburg, J. J. and Levin, L. A.: Coastal hypoxia and sediment biogeochemistry, Biogeosciences, 6, 1273-1293, 2009, http://www.biogeosciences.net/6/1273/2009/.

Mouillot, D., Villeger, S., Scherer-Lorenzen, M., and Mason, N. W. H.: Functional structure of biological communities predicts ecosystem multifunctionality, PloS One, 6, e17476, doi:10.1371/journal.pone.0017476, 2011.

Mouillot, D., Bellwood, D. R., Baraloto, C., Chave, J., Galzin, R., Harmelin-Vivien, M., Kulbicki, M., Lavergne, S., Lavorel, S., Mouquet, N., Paine, C. E. T., Renaud, J., and Thuiller, W.: Rare species support vulnerable functions in high-diversity ecosystems, PLoS Biol., 11, e1001569, doi:10.1371/journal.pbio.1001569, 2013.

Munari, C. and Mistri, M.: Short-term hypoxia modulates Rapana venosa (Muricidae) prey preference in Adriatic lagoons, J. Exp. Mar. Biol. Ecol., 407, 166-170, 2011.

Nestlerode, J. A. and Diaz, R. J.: Effects of periodic environmental hypoxia on predation of a tethered polychaete, Glycera americana: implications for trophic dynamics, Mar. Ecol.-Prog. Ser., 172, 185-195, 1998.

Nilsson, H. C. and Rosenberg, R.: Hypoxic response of two marine benthic communities, Mar. Ecol.-Prog. Ser., 115, 209-217, 1994.

Officer, C. B., Smayda, T. J., and Mann, R.: Benthic filter feeding: a natural eutrophication control, Mar. Ecol.-Prog. Ser., 9, 203-210, 1982.

O’Gorman, E. J., Yearsley, J. M., Crowe, T. P., Emmerson, M. C., Jacob, U., and Petchey, O. L.: Loss of functionally unique species may gradually undermine ecosystems, P. R. Soc. Lond. B, 278, 1886-1893, 2011.

Ott, J. and Fedra K.: Stabilizing properties of a high-biomass benthic community in a fluctuating ecosystem, Helgoländer wiss. Meeresunters., 30, 485-494, 1977.
Pearson, T. H. and Rosenberg, R.: Macrobenthic succession in relation to organic enrichment and pollution of the marine environment, Oceanogr. Mar. Biol. Ann. Rev., 16, 229-311, 1978.

Pihl, L., Baden, S. P., Diaz, R. J., and Schaffner, L. C.: Hypoxiainduced structural changes in the diet of bottom-feeding fish and crustacean, Mar. Biol., 112, 349-361, 1992.

Pörtner, H. O., Langenbuch, M., and Michaelidis, B.: Synergistic effects of temperature extremes, hypoxia, and increases in $\mathrm{CO}_{2}$ on marine animals: from earth history to global change, J. Geophys. Res.-Oceans, 110, C09S10, doi:10.1029/2004JC002561, 2005.

Pretterebner, K., Riedel, B., Zuschin, M., and Stachowitsch, M.: Hermit crabs and their symbionts: Reactions to artificially induced anoxia on a sublittoral sediment bottom, J. Exp. Mar. Biol. Ecol., 411, 23-33, 2012.

Rabalais, N. N., Harper, D. E. Jr., and Turner, R. E.: Responses of nekton and demersal and benthic fauna to decreasing oxygen concentrations, in: Coastal Hypoxia: Consequences for Living Resources and Ecosystems, Coastal and Estuarine Studies, edited by: Rabalais, N. N. and Turner, R. E., 58, 115-128, Am. Geophys. Union, Washington, DC, 2001.

Rabalais, N. N., Díaz, R. J., Levin, L. A., Turner, R. E., Gilbert, D., and Zhang, J.: Dynamics and distribution of natural and humancaused hypoxia, Biogeosciences, 7, 585-619, doi:10.5194/bg-7585-2010, 2010.

Riedel, B., Stachowitsch, M., and Zuschin, M.: Sea anemones and brittle stars: unexpected predatory interactions during induced in situ oxygen crises, Mar. Biol., 153, 1075-1085, 2008a.

Riedel, B., Zuschin, M., Haselmair, A., and Stachowitsch, M.: Oxygen depletion under glass: Behavioural responses of benthic macrofauna to induced anoxia in the Northern Adriatic, J. Exp. Mar. Biol. Ecol., 367, 17-27, 2008b.

Riedel, B., Zuschin, M., and Stachowitsch, M.: Tolerance of benthic macrofauna to hypoxia and anoxia in shallow coastal seas: a realistic scenario, Mar. Ecol.-Prog. Ser., 458, 39-52, 2012.

Roberts, S. J. and Brink, K.: Managing marine resources sustainably, Environment, 52, 44-52, 2010.

Rosenberg, R., Hellman, B., and Johansson, B.: Hypoxic tolerance of marine benthic fauna, Mar. Ecol.-Prog. Ser., 79, 127-131, 1991.

Rufino, M. M., Maynou, F., Abelló, P., and Sardá, F.: Spatial and environmental factors affecting the distribution of the main decapod crustacean prey species in the NW Mediterranean, Hydrobiologia, 555, 129-141, 2006.

Sagasti, A., Schaffner, L. C., and Duffy, J. E.: Effects of periodic hypoxia on mortality, feeding and predation in an estuarine epifaunal community, J. Exp. Mar. Biol. Ecol., 258, 257-283, 2001.

Sala, E. and Knowlton, M.: Global marine biodiversity trends, Annu. Rev. Environ. Resour., 31, 93-122, 2006.

Sandberg, E.: Does short-term oxygen depletion affect predatorprey relationships in zoobenthos? Experiments with the isopod Saduria entomon, Mar. Ecol.-Prog. Ser., 103, 73-80, 1994.

Sandberg, E., Tallqvist, M., and Bonsdorff, E.: The effects of reduced oxygen content on predation and siphon cropping by the brown shrimp, Crangon crangon, P.S.Z.N.I: Mar. Ecol., 17, 411423, 1996.

Sassaman, C. and Mangum, C. P.: Adaptions to environmental oxygen levels in infaunal and epifaunal sea anemones, Biol. Bull. (Woods Hole), 143, 657-678, 1972. 
Seibel, B. A.: Critical oxygen levels and metabolic suppression in oceanic oxygen minimum zones, J. Exp. Biol., 204, 326-336, 2011.

Seitz, R. D., Marshall, L. S., Hines, A. H., Clark, K. L.: Effects of hypoxia on predator-prey dynamics of the blue crab Callinectes sapidus and the Baltic clam Macoma balthica in Chesapeake Bay, Mar.-Ecol. Prog. Ser.: 257, 179-188, 2003.

Shick, J. M. (Ed.): A functional biology of sea anemones, 395 pp., Chapman \& Hall, New York, 1991.

Shimps, E. L., Rice, J. A., and Osborne, J. A.: Hypoxia tolerance in two juvenile estuary-dependent fishes, J. Exp. Mar. Biol. Ecol., 325, 146-162, 2005.

Schinner, G. O.: Burrowing behavior, substratum preference, and distribution of Schizaster canaliferus (Echinoidea: Spatangoida) in the northern Adriatic Sea, Mar. Ecol., 14, 129-145, 1993.

Sibley, P. K., Chappel, M. J., George, T. K., Solomon, K. R., and Liber, K.: Integrating effects of stressors across levels of biological organization: examples using organophosphorus insecticide mixtures in field-level exposures, J Aquat. Ecosyst. Stress Recov., 7, 117-130, 2000.

Sih, A., Ferrari, M. C. O., and Harris, D. J.: Evolution and behavioral responses to human-induced rapid environmental change, Evol. Appl., 4, 367-387, 2011.

Solan, M., Cardinale, B. J., Downing, A. L., Engelhardt, K. A., Ruesink, J. L., and Srivastava, D. S.: Extinction and ecosystem function in the marine benthos, Science, 306, 1177-1180, 2004.

Spicer, J. I.: What can an ecophysiological approach tell us about the physiological responses of marine invertebrates to hypoxia?, J. Exp. Biol., 217, 46-56, 2014.

Smith, V. H. and Schindler, D. W.: Eutrophication science: where do we go from here?, Trends Ecol. Evol., 24, 201-207, 2009.

Stachowitsch, M.: Mass mortality in the Gulf of Trieste: the course of community destruction, P.S.Z.N.I: Mar. Ecol., 5, 243-264, 1984.

Stachowitsch, M.: Anoxia in the Northern Adriatic Sea: Rapid death, slow recovery, Geol. Soc. Spec. Publ., 58, 119-129, 1991.

Stachowitsch, M. and Fuchs, A.: Long-term changes in the benthos of the Northern Adriatic Sea, Annales, 7, 7-16, 1995.

Stachowitsch, M., Riedel, B., Zuschin, M., and Machan, R.: Oxygen depletion and benthic mortalities: the first in situ experimental approach to documenting an elusive phenomenon, Limnol. Oceanogr.-Methods, 5, 344-352, 2007.

Stauber, L. A.: Pinnotheres ostreum, parasitic on the American oyster, Ostrea (Gryphaea) virginica, Biol. Bull. (Woods Hole), 88, 269-291, 1945.

Tallqvist, M.: Burrowing behaviour of the Baltic clam Macoma balthica: effects of sediment type, hypoxia and predator presence, Mar. Ecol.-Prog. Ser., 212, 183-191, 2001.

Taylor, D. L. and Eggleston, D. B.: Effects of hypoxia on an estuarine predator-prey interaction: foraging behavior and mutual interference in the blue crab Callinectes sapidus and the infaunal clam prey Mya arenaria, Mar. Ecol.-Prog. Ser., 196, 221-237, 2000.

Taylor, E. W., Butler, P. J., and Al-Wassia, A.: Some responses of the shore crab, Carcinus maenas (L.), to progressive hypoxia at different acclimation temperatures and salinities, J. Comp. Physiol., 122, 391-402, 1977.
Thayer, G. W., Schaaf, W. E., Angelovic, J. W., and LaCroix, M. W.: Caloric measurements of some estuarine organisms, Fish. Bull., 71, 289-296, 1973.

Thorson, G.: Parallel level-bottom communities, their temperature adaptation, and their "balance" between predators and food animals, in: Perspectives in marine biology, edited by: BuzzataTraverso, A. A., 67-86, University of California Press, Berkeley, California, 1957.

Thrush,, S. F. and Dayton, P. K.: Disturbance to marine benthic habitats by trawling and dredging: implications for marine biodiversity, Annu. Rev. Ecol. Syst., 33, 449-473, 2002.

Thrush, S. F., Hewitt, J., Gibbs, M., Lundquist, C., and Norkko, A.: Functional role of large organisms in intertidal communities: community effects and ecosystem function, Ecosystems, 9, 1029-1040, 2006.

Tilman, D., Knops, J., Wedin, D., Reich, P., Ritchie, M., and Siemann, E.: The influence of functional diversity and composition on ecosystem processes, Science, 277, 1300-1302, 1997.

Tuomainen, U. and Candolin, U.: Behavioural responses to humaninduced environmental change, Biol. Rev., 86, 640-657, 2011.

UNEP: Marine and coastal ecosystems and human wellbeing: A synthesis report based on the findings of the Millennium Ecosystem Assessment, UNEP, 76 pp., 2006.

Vaquer-Sunyer, R. and Duarte, C. M.: Thresholds of hypoxia for marine biodiversity, P. Natl. Acad. Sci. USA, 105, 15452-15457, 2008.

Vaquer-Sunyer, R. and Duarte, C. M.: Sulfide exposure accelerates hypoxia-driven mortality, Limnol. Oceanogr., 55, 1075-1082, 2010.

Vaquer-Sunyer, R. and Duarte, C. M.: Temperature effects on oxygen thresholds for hypoxia in marine benthic organisms, Glob. Change Biol., 17, 1788-1797, 2011.

Verberk, W. C., Bilton, D. T., Calosi, P., and Spicer, J. I.: Oxygen supply in aquatic ectotherms: partial pressure and solubility together explain biodiversity and size patterns, Ecology, 92, 1565$1572,2011$.

Vistisen, B. and Vismann, B.: Tolerance to low oxygen and sulfide in Amphiura filiformis and Ophiura albida (Echinodermata: Ophiuroidea), Mar. Biol., 128, 241-246, 1997.

Wahl, M.: The fluffy sea anemone Metridium senile in periodically oxygen depleted surroundings, Mar. Biol., 81, 81-86, 1984.

Ward, J. E. and Shumway, S. E.: Separating the grain from the chaff: particle selection in suspension and deposit-feeding bivalves, J. Exp. Mar. Biol. Ecol., 300, 83-130, 2004.

Wicksten, M. K.: A review and a model of decorating behavior in spider crabs (Decapoda, Brachyura, Majidae), Crustaceana, 64, 314-325, 1993.

Worm, B., Barbier, E. B., Beaumont, N., Duffy, J. E., Folke, C., Halpern, B. S., Jackson, J. B. C., Lotze, H. K., Micheli, F., Palumbi, S. R., Sala, E., Selkoe, K. A., Stachowicz, J. J., and Watson, R.: Impacts of biodiversity loss on ocean ecosystem services, Science, 314, 787-790, 2006.

Wu, R. S. S.: Hypoxia: from molecular responses to ecosystem responses, Mar. Pollut. Bull., 45, 35-45, 2002.

Wu, R. S. S.: Effects on fish reproduction and development, Fish Physiol., 27, 79-141, 2009.

Wurzian, R. S.: Predator - prey interaction between the crab Pilumnus hirtellus (Leach) and the brittle star Ophiothrix quinquemaculata (D.Chiaje) on a mutual sponge substrate, in: Biology of 
Benthic Organisms, 11th Eur. Mar. Biol. Symp., edited by: Keegan, B. F., O'Ceidigh, P., and Boaden P. J. S., Galway, 613-620, Pergamon Press, Oxford, 1977.

Xu, J., Liu, Y., Cui, S., and Miao, X.: Behavioral responses of tilapia (Oreochromis niloticus) to acute fluctuations in dissolved oxygen levels as monitored by computer vision, Aquat. Eng., 35, 207217, 2006.
Zhang, J., Gilbert, D., Gooday, A. J., Levin, L., Naqvi, S. W. A., Middelburg, J. J., Scranton, M., Ekau, W., Peña, A., Dewitte, B., Oguz, T., Monteiro, P. M. S., Urban, E., Rabalais, N. N., Ittekkot, V., Kemp, W. M., Ulloa, O., Elmgren, R., Escobar-Briones, E., and Van der Plas, A. K.: Natural and human-induced hypoxia and consequences for coastal areas: synthesis and future development, Biogeosciences, 7, 1443-1467, doi:10.5194/bg-7-14432010, 2010. 


\section{Appendix A}

Table A1. Summary of the 11 deployments. No.: number of deployment; ww: wet weight; -: no data.

\begin{tabular}{|c|c|c|c|c|c|c|c|c|c|}
\hline \multirow[t]{2}{*}{ No. } & \multirow{2}{*}{$\begin{array}{l}\text { Date } \\
\text { dd.mm.yyyy }\end{array}$} & \multicolumn{2}{|c|}{ Duration deployment (h) } & \multicolumn{2}{|c|}{ Duration (h) } & \multirow{2}{*}{$\begin{array}{r}\mathrm{H}_{2} \mathrm{~S}(\mu \mathrm{M}) \\
\text { average }\end{array}$} & \multirow{2}{*}{$\begin{array}{r}\mathrm{pH} \\
\text { final } \\
\text { last } \mathrm{h}\end{array}$} & \multirow{2}{*}{$\begin{array}{r}\text { Temp. } \\
{ }^{\circ} \mathrm{C}\end{array}$} & \multirow{2}{*}{$\begin{array}{r}\text { Biomass (total) } \\
\mathrm{g} \mathrm{ww} \\
0.25 \mathrm{~m}^{-2}\end{array}$} \\
\hline & & $\begin{array}{r}\text { open } \\
\text { (frame) }\end{array}$ & $\begin{array}{r}\text { closed } \\
(\text { chamber })\end{array}$ & hypoxia & anoxia & & & & \\
\hline 2 & 17.-22.09.2005 & - & 132.8 & 20.1 & 81.8 & 167.6 & - & 18.5 & 436.7 \\
\hline 3 & 24.-27.09.2005 & - & 69.4 & 46.1 & 5.2 & 5.5 & - & 17.8 & 682.1 \\
\hline 4 & 27.09.-01.10.2005 & - & 101.6 & 41.6 & 28.8 & 36.8 & - & 17.6 & 604.7 \\
\hline 6 & 05.-08.08.2006 & 22.4 & 48.3 & 12.5 & 22.9 & 5.2 & 7.9 & 18.8 & - \\
\hline 7 & 17.-21.09.2006 & 20.9 & 72.1 & 33.8 & 28.7 & 124.2 & 7.7 & 19.7 & 839.8 \\
\hline 8 & 21.-24.09.2006 & 21.7 & 41.9 & 22.7 & 8.5 & 0.0 & - & 20.4 & 526.3 \\
\hline 9 & 25.-29.09.2006 & 21.9 & 73 & 40.5 & 19.1 & 19.3 & 7.8 & 20.6 & 648.9 \\
\hline 10 & 29.09.-02.10.2006 & 22.7 & 40.3 & 16.7 & 13.9 & 11.8 & 7.9 & 21.4 & 629.2 \\
\hline 11 & 05.-10.10.2006 & 23.6 & 95.4 & 11.4 & 78.3 & 106.7 & 7.5 & 21.3 & 724.0 \\
\hline 12 & 10.-14.10.2006 & 25.4 & 75.2 & 33.6 & 24.2 & 18.2 & 7.8 & 21.3 & 631.6 \\
\hline 13 & 17.-21.10.2006 & - & 94.6 & 52.9 & 25.1 & 124.5 & 7.8 & 20.4 & 1042.7 \\
\hline
\end{tabular}


Table A2. Macrobenthic species (32 species and 2 species groups) recorded. Group abbreviation: Ant: Anthozoa, Nem: Nemertini, Sip: Sipunculida, Gas: Gastropoda, Biv: Bivalvia, Pol: Polychaeta, Dec: Decapoda, Hol: Holothuroidea, Ech: Echinoidea, Oph: Ophiuroidea, Asc: Ascidiacea. Life habit: epi: epifauna, in: infauna, cry: cryptic fauna; SF: suspension feeder, P: predator, D: deposit feeder. Behaviour subcategories: ${ }^{1}$ visible, non-visible; ${ }^{2}$ horizontal, vertical (both minor, major), no locomotion; ${ }^{3}$ open, half-open, closed; ${ }^{4}$ up-, side-, downward orientated; ${ }^{5}$ bottom, middle $\left(<5 \mathrm{~cm}\right.$ above sediment), high/top $(>5 \mathrm{~cm}) ;{ }^{6 \mathrm{a}}$ column; ${ }^{6 \mathrm{~b}}$ tentacles and oral disc: original, discoloured; 7 normal, "puckered"; 8 normal, protruded; ${ }^{9}$ intact, peeled off; ${ }^{10}$ minor, major; ${ }^{11}$ overturned/moribund; ${ }^{12}$ retracted, extended; ${ }^{13}$ upright, overturned; ${ }^{14}$ closed, half-open, normal, widely gaping; ${ }^{15}$ normal, swollen, retracted; ${ }^{16}$ extended, partially retracted, fully retracted; 17 inside burrow, outside (on sediment); ${ }^{18}$ normal, discarded; ${ }^{19}$ normal, extended, out of shell; ${ }^{20}$ suspension feeding, arm-tipping, arms down/moribund; - not evaluated/applicable.

\begin{tabular}{|c|c|c|c|c|c|c|c|c|c|c|}
\hline Group & Species & $N$ & Life habits & $\begin{array}{l}\text { Visi- } \\
\text { bility }\end{array}$ & $\begin{array}{l}\text { Loco- } \\
\text { motion }\end{array}$ & Movement & Body posture & $\begin{array}{l}\text { Loca- } \\
\text { tion }^{5}\end{array}$ & $\begin{array}{l}\text { Inter- } \\
\text { action }\end{array}$ & Species-specific responses \\
\hline Ant & Calliactis parasitica & 6 & epi, ses, SF & + & - & rotation, detachment & $\begin{array}{l}\text { contraction, crown habitus }{ }^{3} \\
\text { and orientation }\end{array}$ & - & + & $\begin{array}{l}\text { discolouration }{ }^{6 \mathrm{a}}, \text { mouth }^{7}, \\
\text { pharynx }^{8}, \text { acontia }^{1}, \text { periderm }^{9}\end{array}$ \\
\hline Ant & Cereus pedunculatus & 17 & epi, ses, SF & - & - & rotation & $\begin{array}{l}\text { contraction, crown habitus }{ }^{3} \text {, } \\
\text { retraction, extension }{ }^{10}\end{array}$ & - & + & $\begin{array}{l}\text { discolouration }{ }^{6 \mathrm{~b}}, \text { mouth }^{7} \text {, } \\
\text { pharynx } 8\end{array}$ \\
\hline Nem & Tubulanus sp. & 1 & in, mob, $\mathrm{P}$ & + & + & squirm & - & - & - & - \\
\hline Sip & indet. species & 4 & in, mob, D & + & + & squirm & - & - & - & - \\
\hline Gas & Diodora sp. & 4 & epi, mob, P & + & + & - & orientation $^{11}$, foot habitus ${ }^{12}$ & - & - & - \\
\hline Gas & Fusinus rostratus & 1 & epi, mob, P & + & + & - & foot habitus 12 & + & - & - \\
\hline Gas & Hexaplex trunculus & 23 & epi, mob, $P$ & + & + & turn, shell orientation ${ }^{13}$ & foot habitus ${ }^{12}$ & + & - & - \\
\hline Gas & Murex brandaris & 1 & epi, mob, P & + & + & turn & - & + & - & - \\
\hline Biv & Abra alba & 2 & in, mob, D & + & + & - & siphon $^{1}$ & - & - & - \\
\hline Biv & Chlamys varia & 7 & epi, mob, SF & - & + & - & valve gape ${ }^{14}$ & - & + & mantle tissue $^{15}$ \\
\hline Biv & Corbula gibba & 37 & in, mob, SF & + & + & - & - & - & - & - \\
\hline Biv & $\begin{array}{l}\text { Venerupis } \\
\text { cf. rhomboides }\end{array}$ & 1 & in, mob, SF & + & + & - & foot habitus ${ }^{12}$, siphon $^{1}$ & - & - & - \\
\hline Pol & indet. species & 17 & in, mob, D/P & + & + & squirm & - & - & - & \\
\hline Pol & Glycera sp. & 1 & in, $\mathrm{mob}, \mathrm{P}$ & + & + & squirm & - & - & - & - \\
\hline Pol & Protula tubularia & 8 & epi, ses, SF & - & - & - & crown extension ${ }^{16}$ & - & + & - \\
\hline Dec & Alpheus glaber & 2 & epi, mob, D & + & + & body and extremity, turn & orientation $^{11}$ &,$+{ }^{17}$ & + & - \\
\hline Dec & Ebalia tuberosa & 3 & epi, mob, P & + & + & body and extremity, turn & - & + & + & - \\
\hline Dec & Ethusa mascarone & 3 & epi/cryp, mob, $\mathrm{P}$ & + & + & body and extremity, turn & - & + & + & camouflage $^{18}$ \\
\hline Dec & Eurynome aspera & 2 & epi, mob, P & + & + & body and extremity, turn & - & + & + & - \\
\hline Dec & Galathea spp. & 3 & epi/cryp, mob, $\mathrm{P}$ & + & + & body and extremity, turn & - & + & + & - \\
\hline Dec & Inachus sp. & 1 & epi, mob, P & + & + & body and extremity, turn & - & + & + & - \\
\hline Dec & Macropodia spp. & 7 & epi, mob, P & + & + & body and extremity, turn & - & + & + & - \\
\hline Dec & $\begin{array}{l}\text { Nepinnotheres } \\
\text { pinnotheres }\end{array}$ & 2 & epi/cryp, mob, $\mathrm{P}$ & + & + & body and extremity, turn & - & + & + & host abandonment \\
\hline Dec & Paguristes eremita & 25 & epi, mob, P & + & + & body, turn & posture $^{19}$ & + & + & shell orientation ${ }^{13}$ \\
\hline Dec & Pilumnus spinifer & 17 & epi/cryp, mob, $\mathrm{P}$ & + & + & body and extremity, turn & - & + & + & - \\
\hline Dec & Pisidia longimana & 4 & epi/cryp, mob, $\mathrm{P}$ & + & + & body and extremity, turn & - & + & + & - \\
\hline Hol & Ocnus planci & 4 & epi, mob, SF & - & + & - & $\begin{array}{l}\text { contraction, elongation }{ }^{10} \text {, } \\
\text { crown habitus }^{3} \text { and } \\
\text { orientation }^{4}\end{array}$ & - & + & - \\
\hline Ech & $\begin{array}{l}\text { Psammechinus } \\
\text { microtuberculatus }\end{array}$ & 17 & epi, mob, D & + & + & spine movement & - & - & - & camouflage \\
\hline Ech & Schizaster canaliferus & 22 & in, mob, D & + & + & spine movement & orientation $^{11}$ & - & - & sediment bulging \\
\hline Oph & $\begin{array}{l}\text { Ophiothrix } \\
\text { quinquemaculata }\end{array}$ & 28 & epi, mob, SF & + & + & - & body habitus ${ }^{20}$ & + & + & fragmentation \\
\hline Oph & Ophiura spp. & 3 & inf, mob, D & + & + & - & - & - & + & fragmentation \\
\hline Oph & Amphiura chiajei & 10 & inf, mob, D & + & + & - & - & - & + & arm tips ${ }^{1}$, fragmentation \\
\hline Asc & Microcosmus spp. & 10 & epi, ses, SF & - & - & - & $\begin{array}{l}\text { siphon habitus }{ }^{3} \text { and elongation, } \\
\text { contraction, drooping }\end{array}$ & - & + & - \\
\hline Asc & Phallusia mammilata & 9 & epi, ses, SF & - & - & - & $\begin{array}{l}\text { siphon habitus }{ }^{3} \text {, contraction, } \\
\text { drooping }\end{array}$ & - & + & - \\
\hline
\end{tabular}

